Article

\title{
An Examination of Ethnic Hierarchies and Returns to Human Capital in the UK
}

\author{
Wouter Zwysen * and Neli Demireva \\ Department of Sociology, University of Essex, Colchester, CO4 3SQ, UK; E-mails: wzwyse@essex.uk (W.Z.), \\ nvdem@essex.uk (N.D.) \\ * Corresponding author
}

Submitted: 1 March 2018 | Accepted: 16 May 2018 | Published: 30 July 2018

\begin{abstract}
This article focuses on the returns to human capital of migrants and minorities in the UK. The question of whether skills and qualifications are properly utilized is very pertinent given the global competition for skilled migrants and the aim of European and British markets to attract such workers. Using data from Understanding Society (2009 to 2017) we find that there is a clear evidence of ethnic hierarchies with black Caribbean and black African minorities generally most disadvantaged, while other white UK-born have the best outcomes compared to the white British. Western migrants generally do very well, but new EU migrants have high levels of employment, and low returns to their qualifications and relatively high levels of over-qualification. Foreign qualifications are generally discounted, and more so for migrants with less certain legal status or low language skills. Public sector employment plays an important role and is associated with the higher economic placement of migrants and minorities in the UK. There are some worrying trends however. Highly skilled migrants, particularly black migrants as well as those from Eastern Europe, come in with high qualifications, but their jobs do not match their skill levels.
\end{abstract}

\section{Keywords}

ethnicity; international migration; labour market; over-qualification

\section{Issue}

This article is part of the issue "The Race for Highly-Skilled Workers", edited by Neli Demireva (University of Essex, UK) and Ivana Fellini (University of Milano Bicocca, Italy).

(C) 2018 by the authors; licensee Cogitatio (Lisbon, Portugal). This article is licensed under a Creative Commons Attribution 4.0 International License (CC BY).

\section{Introduction}

This article focuses on the labour market integration of migrants and minorities in UK, and the returns to human capital among different ethnic groups. The question whether skills and qualifications are properly utilized is very pertinent given the global competition for skilled migrants and the aim of European markets to attract such workers (Damas de Matos \& Liebig, 2014). The economic integration of migrants and minorities is part of a wider conversation about equity and social cohesion and played an important role in the Brexit debates. Currently, both the Conservative government and the Labour party in opposition hold on to an ambition of reducing net mi- gration and keeping migration under firm control. A decision however to curb migration to the 'tens of thousands' (The Conservative and Unionist Party, 2017) might come into direct conflict with plans to attract and ensure the inflow of highly skilled workers.

It is usually assumed that migrants' qualifications will not be fully transferable because they lack knowledge of the operation of the local labour market. Consecutive generations, born and raised in the UK, should not be exposed to the same process of discounting and knowledge adaptation that blighted their migrant parents. Yet, despite substantial increases in qualifications obtained over time and generations, labour market gaps are found to persist even for UK-born ethnic minority workers (e.g., 
Algan, Dustmann, Glitz, \& Manning, 2010; Dustmann \& Theodoropoulos, 2010). Such inability to match work and qualification levels is problematic and represents a loss for the UK as it signals the underutilization of skills and leads to a persistence of migrant and ethnic disadvantage within the UK.

Using data from Understanding Society, a representative UK panel study with a large ethnic minority boost sample (Knies, 2017), we analyse gaps in the employment and the probability of finding work appropriate to their skills for highly-skilled migrants and UK-born ethnic minorities comparing them to the white British majority. The article answers several pertinent questions. First, it describes the degree of transferability of migrants' qualifications and the importance of further human capital acquisitions for their labour market placement. We go beyond previous studies by considering heterogeneity in the returns to UK and foreign qualifications. Second, the article makes use of a large and recent data-set which includes an ethnic minority boost sample allowing for a detailed break-down of migrants and UK-born ethnic minorities compared to the white British majority. The previous literature on the topic has focused mainly on the dated Fourth National Survey of Ethnic Minorities 1993-1994 (e.g., Battu \& Sloane, 2004) and the UK Labour Force Survey (LFS) (e.g., Lindley, 2009), and this timely analysis represents an important contribution. Finally, we study differences between the public and private sector to comment on the possible role of hiring discrimination, which is generally substantially larger in the private sector (Wood, Hales, Purdon, Sejersen, \& Hayllar, 2009). This highlights the difference by sectors in the extent to which skills are put to use. By considering the role of education as to a variety of labour market outcomes and comparing the white British majority to migrants and ethnic minorities within one framework, this article contributes to the growing literature on labour market integration of highly educated migrants and ethnic minorities in the UK.

\section{Background}

Migrants in the UK are consistently found less likely to be employed than the white British majority. When employed, they tend to work on lower quality jobs and have lower earnings (e.g., Demireva \& Kesler, 2011; Dustmann \& Theodoropoulos, 2010; Li \& Heath, 2008). There is evidence of clear polarization as migrants to the UK tend to be somewhat more highly educated than the white British majority on average, although this pattern differs between groups, but they are also more likely to arrive with very low qualifications (Dustmann \& Theodoropoulos, 2010).

Within the general economic assimilation framework, migrants' labour market outcomes are expected to be lower both compared to their own position before migration and compared to similar majority members, as migrants lack host country specific human capital in the resident society (Chiswick, 1978, 2009; Duleep \& Regets, 1999). Higher qualified migrants in particular may be at a disadvantage if their qualifications are not trusted or recognized by employers and are discounted. Over time, as migrants learn the customs and language, and acquire social networks and resources, these disadvantages should decrease. Further investments in host country human capital are also expected to benefit the more highly qualified as they increase the transferability of previously held qualifications (Duleep \& Regets, 1999).

Indeed, Damas de Matos and Liebig (2014) show that the average migrant receives low returns to their qualifications, more so in Europe than in the US. They point to two barriers in transferring qualifications-namely a lack of language skills and employers not recognizing foreign qualifications as equivalent-and show that returns to qualifications are substantially higher for migrants who report better language skills and for those who obtained equivalence of their foreign degrees. Previous research has indicated that, even in countries such as Canada with a highly selective inflow of migrants through a points-based system, migrants' high qualifications are discounted and essentially worthless on the labour market in the short term (Aydemir, 2011).

These hurdles towards full labour market integration and equal valuation of qualifications should not be present for ethnic minorities born in the country, who received training in the receiving society. Contrary to this positive expectation, studies on generational improvement generally find persistent ethnic penalties in employment, earnings and occupational status for UK born minorities despite an improvement in education (e.g., Algan et al., 2010; Cheung, 2013; Dustmann \& Theodoropoulos, 2010). These patterns are all the more puzzling because education has substantially increased over time and generations, with UK-born ethnic minorities generally more likely to be highly qualified than the white British (Modood, 2005). It is therefore very relevant to study the extent to which different qualifications can improve the economic standing of individuals.

It is important to consider not only employment, but also whether migrants and minorities work on jobs that match their qualifications. Working on a job for which one is over-qualified does not have to be problematic in itself, as it can reflect genuine heterogeneity in skills within qualification levels, is associated with generally higher pay than those doing the same job with matched qualifications and, especially for migrants, may also still represent a significant improvement in pay from the situation in the origin country (Borjas, Kauppinen, \& Poutvaara, 2018; Green \& Mclntosh, 2007; Quintini, 2011). Previous research does suggest a disproportionally high risk for migrants and ethnic minorities of working on jobs for which they are over-qualified, as well as lower returns to this over-qualification meaning their qualifications are generally disregarded (Battu \& Sloane, 2004; Lindley, 2009). While this is problematic for individuals, overqualification can also represent a loss for the host coun- 
try as the hoped-for productivity improvements does not occur (Huber, Landesmann, Robinson, \& Stehrer, 2010).

Several studies have focused specifically on returns to human capital. Using a 1993-1994 sample of ethnic minorities in the UK, Battu and Sloane (2004) show that non-white minorities are generally more at risk of over-education. They also show that foreign qualifications are generally discounted in the sense that they increase the risk of over-education. UK-born minorities are at a disadvantage as they are more likely to be overeducated and also receive no payment bonus for their higher-than-average qualifications while white workers do. In the more credentialist, and possibly less discriminatory, public sector, these disadvantages are generally lower. Lindley (2009) uses the UK LFS to study overeducation for migrants and minorities with UK qualifications and shows that UK-born non-white men and Indian, Pakistani and Bangladeshi women are more likely to be over-qualified than UK-born whites and receive lower returns to their high qualifications. Johnston, Khattab and Manley (2015) use the UK LFS to study over-qualification among West and East European migrants compared to the white British natives. They show especially high overqualification for new EU migrants who are also paid least for their additional qualifications within each job, while West European migrants are very highly qualified and do well on the labour market. Rafferty (2012) shows substantial ethnic penalties in graduate over-education, employment probability and earnings even among the highly qualified British ethnic minorities. He suggests this may be partly explained by differences in socioeconomic status or types of qualifications. Zwysen and Longhi (2018) use detailed data on recent graduates from UK universities to show substantial ethnic gaps in employment and, to a lesser extent, earnings, six months after graduation. Even when accounting for detailed type of degree, parental background and socio-economic status these differences in employment remained.

These studies all indicate that, while higher qualifications are beneficial and lead to better outcomes for migrants and minorities, the actual benefits experienced among these groups are substantially less than those experienced by the white British majority. Worryingly, even UK qualifications are discounted for migrants and ethnic minorities. We build on this literature and expand it by using recent representative data with detailed ethnic groups and migrant status; considering both employment and over-qualification compared to the majority for these detailed groups; and analyzing the conditions under which foreign qualifications are discounted more.

Besides a lower transferability of human capital, these differences may also be due to discrimination. To obtain an indication of the role played by employer decisions-both in uncertainty about qualifications and in discounting them due to statistical discrimination or prejudice-we study differences in ethnic penalties between the public and private sector of employment. Hiring discrimination, estimated through correspondence tests, has been shown to be much lower or even nonexistent, in the more scrutinized public sector in the UK (Wood et al., 2009).

\section{Data and Variables}

In order to answer our questions on labour market outcomes of skilled migrants and minorities we use the seven available waves of Understanding Society, a large and representative UK Household Panel Study which started in 2009 (Knies, 2017). The survey includes an ethnic minority boost sample which oversampled respondents of six large ethnic groups in the UK, as well as having recently added a further immigrant boost sample. We restrict the sample to those of working age (16 to 64) who reported not being in full-time education or training or being retired. After listwise deletion of missing observations the final sample consists of 175,773 observations for 46,514 respondents. We use the provided weights to account for sample selection and attrition over the waves throughout the article.

We consider two main outcomes: first, the probability of being employed rather than inactive or unemployed; second, among those who work, we consider whether the type of job matches respondents' qualifications. There are several ways of measuring whether qualifications are matched, including expert assessments of the requirement of a position, subjective assessments of workers and the statistical method-where the respondents' qualifications are compared to the qualifications of people doing the same or similar work, using the average or mode (Battu \& Sloane, 2004; Quintini, 2011). In this article we use the latter, as it is more readily available and follows previous studies in the UK (e.g., Battu \& Sloane, 2004; Johnston, Khattab, \& Manley, 2015; Lindley, 2009). One drawback may be that this does not capture skills differences within qualifications. We compare workers' education expressed as years, ${ }^{1}$ to the UK average in the 4-digit occupation. The average years of schooling within the occupation is obtained from a detailed set of highest qualifications within 4-digit occupations in pooled quarters of the UK LFS, a large-scale representative survey of workers. As the occupational codes (SOC) change in 2010 we use the 2008 and 2009 LFS to estimate the years of schooling for detailed SOC2000 codes, and LFS 2011 through to 2017 to obtain information at SOC2010 level. These averages and the standard deviation of years of schooling within an occupation were then matched to the Understanding Society sample, with $27 \%$ having SOC2010 codes, and have been used to catego-

\footnotetext{
${ }^{1}$ Respondents to Understanding Society (Knies, 2017) report their highest obtained qualifications, which we converted to the expected years of education for that qualification. Those with higher degrees were assigned 17 years of education; those with a first degree, or nursing/other medical qualifications 16; those with a diploma of higher education, teaching qualifications (not PGCE), or other higher 15; those with A-levels, a Welsh baccalaureate, an international baccalaureate, a Higher (Scottish), or a Certificate of 6th year studies 13 years; those with AS levels or other school certificates 12; those with at most a GCSE, CSE, Standard/O/Lower 11 years, and those with no qualifications were arbitrarily assigned 9 years of education.
} 
rize every worker in each year as either under-qualifiedmeaning their schooling falls 1 standard deviation below the average; matched - their schooling falls within a standard deviation on either side of the average; and overqualified-their schooling is more than one standard deviation above the average. As a sensitivity test, we define over-qualification as being above the modal years of education and find this makes no difference.

We classify respondents into 17 groups based on country of birth and self-reported ethnicity, which is measured according to census categories-essentially a mixture of ethnicity and immigration status. The reference group consists of white British UK-born respondents, the majority population. We further include two categories each-migrant (born abroad) and UK-bornfor other white, Indian, Pakistani and Bangladeshi, other Asian including Chinese, black Caribbean, black African, and other (including mixed) ethnicity. We further split up other white migrants depending on the country of birth, and identify migrants born in one of the 13 post2004 EU member states (new EU migrant), migrants born in the EU15/EEA or Australia, US and Canada (Western migrants), and migrants who are born elsewhere and identify as other white (other white migrant). Such a distinction is particularly important in the discussion of the placement of highly skilled workers and is particularly relevant in the British context since the Brexit debates questioned the contribution of EU migrants from recently joined EU states.

We are particularly interested in the extent to which educational qualifications benefit migrants and UK-born minorities. Qualifications are measured in three categories: having, at most, upper secondary qualifications (low: A-level or equivalent), having further qualifications (middle: post-secondary non-tertiary), and having degree-level qualifications (high: tertiary). Among migrants we also distinguish between those who have obtained any post-secondary qualifications in the UK and those who acquired a degree outside of the UK.

Respondents are classified as working in the public sector if they report their sector as nationalized industry, central or local government or civil service, health authority or NHS trust, or university or grant-funded education establishment rather than private firm or business or a charity or voluntary organization, excluding those in the armed forces.

\section{Methodology}

\subsection{Differences by Migrant and Ethnic Status by Qualification}

To answer our main question on the pattern of labour market outcomes among migrants and UK-born minorities compared to the UK-born white British we estimate differences in the probability of employment and the probability of being over-qualified rather than having matching or too low qualifications $(Y)$ as shown in equa- tion 1. These models are estimated through binary logistic regression. All analyses are weighted, and standard errors are clustered by unique person-identifier to account for repeated observations. $X$ includes control variables: age, whether respondents cohabit with a partner or are married, self-reported health (fair or poor rather than excellent or good), as well as the year of the interview and government office region. To estimate whether higher qualifications benefit migrants and minorities we include an interaction term between origin $(O r)$ and highest obtained qualifications $(E d)$. We report results as the difference in predicted probabilities of being in each outcome for each migrant/minority group compared to white British workers with similar qualifications, estimated at the grand margin.

$$
Y=F\left(\beta_{0}+\beta_{1} \times X+\beta_{2} \times E d+\beta_{3} \times O r+\beta_{4} \times \operatorname{Or} \times E d+\varepsilon\right)
$$

\subsection{Migrant Returns to Foreign and UK Qualifications}

In a second analysis (equation 2) we study differences in the returns to foreign and UK post-secondary qualifications compared to having lower qualifications specifically for migrants. We then include three interactions in three separate models to study whether the returns to foreign and UK qualifications depends on host country acquisitions, namely whether migrants report any difficulties in speaking English in day-to-day conversations, on the phone, reading English or filling in forms in English (language), are citizens (citizen), and their years of residence (yor). On average, we would expect foreign qualifications to be discounted, but less so for those who are otherwise more integrated (through citizenship, good language skills and having lived in the UK for longer). Due to a smaller sample size we do not differentiate between origin groups in these analyses.

$$
\begin{aligned}
Y & =F\left(\beta_{0}+\beta_{1} \times X+\beta_{2} \times E d_{U K}+\beta_{3} \times E d_{f g n}+\beta_{4} \times\right. \\
& \times \text { citizen }+\beta_{5} \times \text { language } \beta_{6} \times \text { yor }+ \\
& +\varepsilon[\text { base }]+\gamma_{1} \times E d_{U K} \times \text { citizen }+\gamma_{2} \times E d_{f g n} \times \\
& \times \text { citizen }[\text { Model } 1]+\delta_{1} \times E d_{U K} \times \text { language }+ \\
& +\delta_{2} \times E d_{f g n} \times \text { language }[\text { Model } 2]+\theta_{1} \times \\
& \left.\times E d_{U K} \times \text { yor }+\theta_{2} \times E d_{f g n} \times \text { yor }[\text { Model } 3]\right)
\end{aligned}
$$

\subsection{Differences by Sector}

The final model tests whether ethnic and migrant penalties in the probability of being over-qualified differ between the public and private sector by interacting origin and working in the public rather than private sector as shown in equation 3 . As the public sector ought to be both more credentialist and less discriminating, we expect lower average gaps with the majority. As there are citizenship restrictions on who can apply to public sector jobs, the sample in this analysis comprises of respondents that are either born in the UK or the EU, or have UK citizenship. We restrict the data to those with post- 
secondary qualifications.

$$
\begin{aligned}
Y & =F\left(\beta_{0}+\beta_{1} \times X+\beta_{2} \times \text { Or }+\gamma_{1} \times \text { Sector }+\right. \\
& \left.+\gamma_{3} \times \text { Sector } \times \text { Or }+\varepsilon\right)
\end{aligned}
$$

\section{Findings and Discussion}

\subsection{Descriptive Statistics}

Full descriptive statistics for our sample are available in Table $A 1(a, b)$ in the supplementary annex, while Table A2 shows the proportion of respondents that are employed as well as the proportion that work on jobs where the average qualifications are higher than their own (under-qualified) or are lower than their own (over-qualified).

The share of highly qualified respondents is substantially higher among migrants than among the white British (25\%) and ranges between 37\% (black African) and $48 \%$ (other Asian), with the exception of Pakistani/Bangladeshi migrants (24\%) and black Caribbean migrants (20\%). The range of migrants with UK qualifications varies immensely between $15 \%$ for new EU member states, over $52 \%$ among Western migrants and up to $81 \%$ for black Caribbean migrants. UK-born ethnic minorities are all more highly qualified than the white British, with the share of graduates ranging between $28 \%$ (black Caribbean) and 57\% (black African). Migrants in our sample appear to be well integrated with high shares of UK citizenship and relatively few reported difficulties with English.

Descriptively there is a clear pattern of UK-born ethnic minorities as well as black Caribbean, black African and Pakistani/Bangladeshi migrants generally being less likely to be employed than the white British, while migrants from new EU countries, Indian and other Asian migrants have relatively high employment probabilities. The employment probability for low-qualified Pakistani and Bangladeshi women stand out at the very bottom of the employment hierarchy. Higher qualifications contribute substantially and positively to the probability of employment for everyone, although the difference between post-secondary non-tertiary and tertiary qualifications on employment is relatively small. The difference in employment by qualification level is generally smaller among migrants, particularly men, than among the white British.

By operationalization, those with higher qualifications are also more likely to be over-qualified than those with low qualifications. Among white British men the risk of over-qualification is $47 \%$ for graduates while it is $41 \%$ for women. The shares of over-qualification among highly qualified migrants are generally substantially higher than those of the white British and of UKborn co-ethnics, with the exception of black Caribbean individuals where migrants are less likely than the white British graduates to be over-qualified, and for black Africans where both UK-born and migrants are at very high risks of over-qualification (75 to 79 percentage points). Over-qualification is very high for migrants from the new EU countries ( $90 \%$ for men and $73 \%$ for women), while the numbers for Western migrants or UK-born other whites are much closer to those of the white British. On average, over-qualification is generally less likely among women than men. Interestingly, it is very uncommon for UK-born minorities and migrants to work on a job for which their qualifications are less than expected. We therefore focus on over-qualification in the analyses. These descriptive patterns are worrying especially given that migrants appear well-integrated in terms of citizenship, and for migrants and minorities in terms of degrees held.

\subsection{Migrant and Minority Gaps in Outcomes}

Figure 1 shows the estimated differences (AME) in the probability of having a job compared to white British workers of the same qualification level who are otherwise similar in terms of socio-demographic characteristics while Figure 2 focuses on the probability of being over-qualified. Full regression results are shown in Table A3 and Table A4 in the supplementary material. A positive effect indicates a higher risk of resp. employment or over-qualification while 0 indicates no difference. In terms of employment the outcomes of white migrants are very similar to those of the white British majority, but the new EU migrants stand out as having very high risks of over-qualification. Contrary to our initial expectations, we do not find a clear gradient and smaller employment gaps for the more highly qualified. Among migrant men the opposite pattern is often found which means their employability decreases with an increase in the qualifications held compared to the white British majority. The largest employment gaps are found for black African migrants and black Caribbean UK-born individuals.

Among female migrants we generally find the most pronounced gaps among the respondents with better qualifications, with the exception of Pakistani/Bangladeshi migrant and UK-born women, where gaps are high among all groups. The patterns for men and women are generally quite similar, although Pakistani and Bangladeshi women do worse than Pakistani and Bangladeshi men, while black Caribbean men do somewhat worse than Black Caribbean women. Overqualification is a substantial problem for all highly qualified male migrant groups, as well as for black African UK-born men.

We should reiterate that while UK-born minorities generally do better than migrants, some groupsparticularly Pakistani and Bangladeshi (especially women), and black Caribbean and black African men regarding resp. employment and over-qualification-are still significantly worse off than their white British counterparts. UK-born other whites generally do better than the white British however. White migrants have generally high employment probabilities, particularly among 

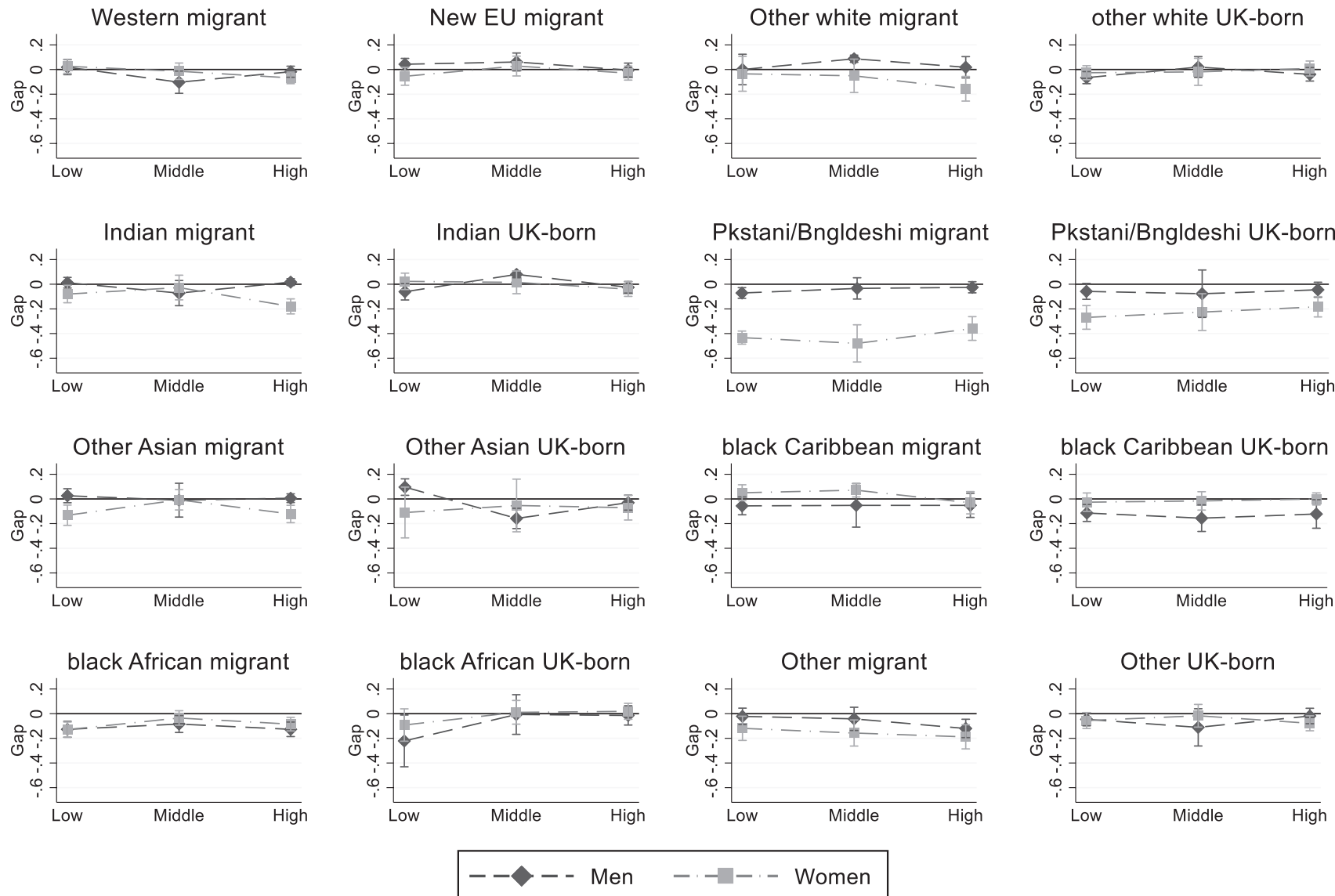

Figure 1. Estimated difference (95\% Confidence interval) from white British majority in probability of employment.

men, however new EU men are very likely to be overqualified. This supports previous findings which indicate that migrants from new EU countries generally worked on less good jobs, possibly due to more cyclical migration patterns and the plan to return back rather than build up a career in the UK (Johnston et al., 2015).

\subsection{Mechanisms behind Low Returns to Migrant Qualifications}

To test the reason behind low returns to higher qualifications for migrants we split up having any postsecondary qualification into those obtained abroad and those obtained in the UK, comparing both to having only upper-secondary qualifications. To test whether the discounting of qualifications varies by other human capital we estimate three further models in which postsecondary qualifications are interacted with having problems with reading, writing or everyday English, whether respondents are UK citizens, and the years of residence (squared). It is relatively rare to have post-secondary UK qualifications, but low language skills (only 111 cases, or $2 \%$ of migrants with UK qualifications) while $14 \%$ of migrants with foreign qualifications have poor English skills. Out of the respondents with foreign post-secondary qualifications in the sample $28 \%$ are not citizens and $15 \%$ have higher UK qualifications.
Figure 3 presents the predicted returns of having foreign post-secondary qualifications and of having UK postsecondary qualifications compared to at most higher secondary qualifications on employment for migrants, estimated as average marginal effects (AME) from binary logistic regression; and Figure 4 shows the probability of being over-qualified. Full regression results are presented in Table A5 and Table A6 in the supplementary material.

A first observation is that the returns to postsecondary qualifications on employment are generally rather small for male migrants, but substantial for women (close to 20 percentage points). The returns to foreign qualifications are generally lower than UK qualifications however, importantly, they are not significantly different from zero for men $(p<0.05)$, although they are associated with better employment outcomes for women. Men with poor English skills do not benefit at all from foreign qualifications. Similarly, the returns to foreign qualifications are higher and significantly different from zero for UK citizens than for those who are not citizens. Both these findings point to foreign qualifications being more discounted in cases of greater uncertainty about the human capital and skills of the applicantse.g., when English proficiency is poor or there are other possible legal hurdles. Among men the returns to foreign qualifications remain low regardless of years of resi- 

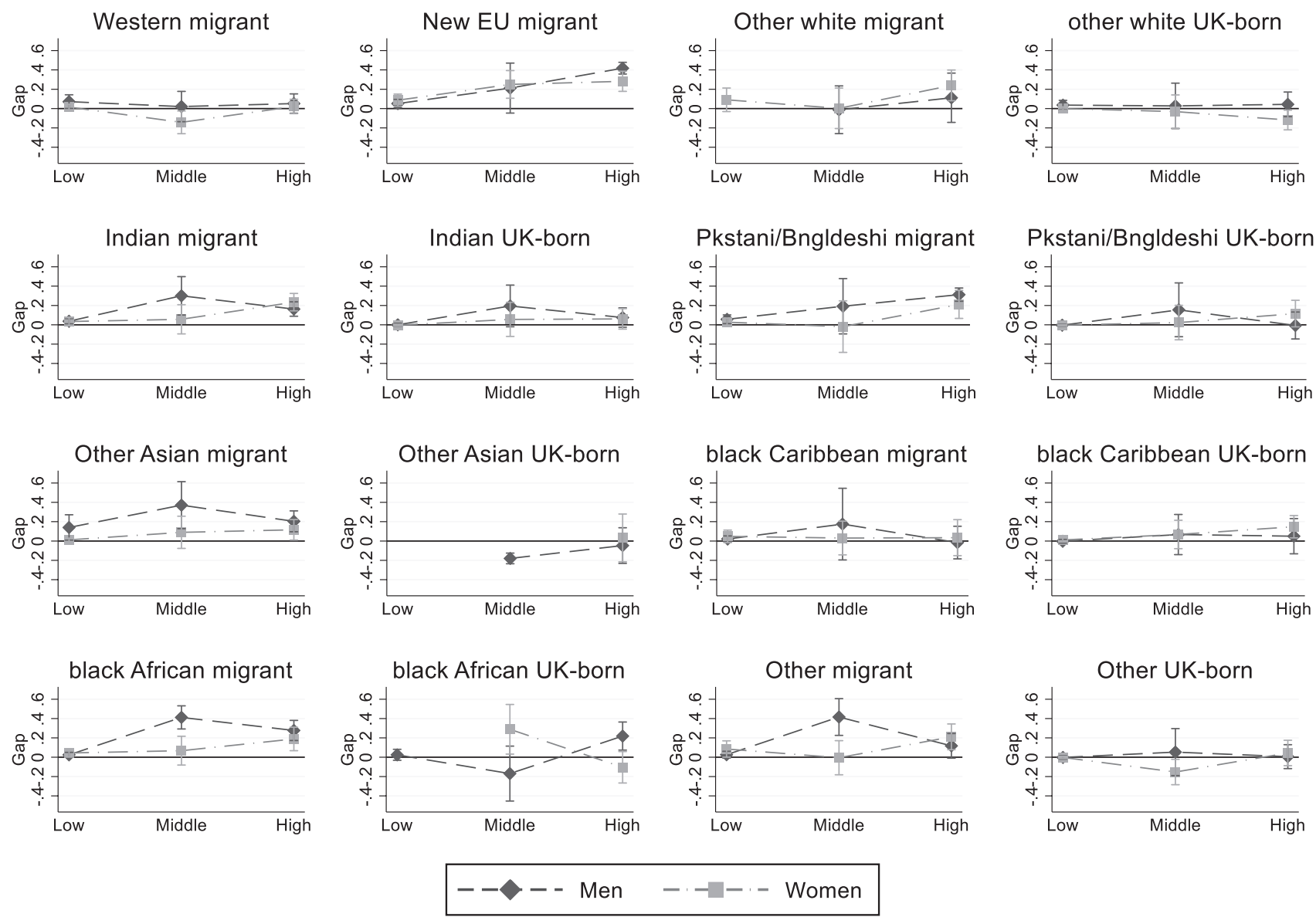

Figure 2. Estimated difference ( $95 \%$ Confidence interval) from white British majority in probability of being over-qualified. Source: Understanding Society 2009-2017 (Knies, 2017), showing the estimated difference in predicted probability at grand margin for origin groups from white British majority by qualification (low: at most upper secondary, middle: postsecondary non-tertiary, or high: tertiary) from weighted binary logistic regression model with clustered standard errors by person. Note: Models control for age (squared), urban, cohabiting, dependent child, poor health, fixed effects for year of survey and government office region, and include qualifications and origin interactions.

dence, but among women the largest discounting occurs among the more recent migrants.

In terms of over-qualification there is very little difference among men, with all those with post-secondary qualifications being more likely than those with at most upper secondary qualifications to be over-qualified. Among women the risk is substantially higher for those with foreign qualifications. There is on the whole little difference by host country acquisitions, although foreign qualifications are generally worse in terms of over-qualification for migrants with poor English than for those with better English skills. As the latter is imprecisely estimated, we should be careful not to overinterpret this pattern.

Our findings indicate that high foreign qualifications are indeed less valuable than UK qualifications and are generally associated with a substantially higher risk of being over-qualified. We find some evidence that foreign qualifications are particularly discounted for migrants who are otherwise less integrated-reporting difficulties with English or not having UK citizenship. This indicates that foreign qualifications may be particularly problem- atic when there is uncertainty about migrant workers. We further find that this difference between foreign and UK qualifications is particularly relevant for women. This may reflect a wider variation in reasons for migration among women, with those with foreign qualifications possibly coming for reasons other than work.

\subsection{Differences by Sector}

This article shows that over-qualification is a substantial issue for migrants and particularly for those with foreign qualifications, while UK-born minorities are not much more likely than their white British counterparts to be over-qualified with the exception of black African men and black Caribbean women. In this final part we study whether there are differences between sectors as selection of minorities into the public sector, which offers more protection from discrimination, may explain differences. Descriptively we find high rates of working in the public sector for other white second generation groups (39\%) and especially black second generation (41\%) with even black migrants (33\%) more likely to work on the 

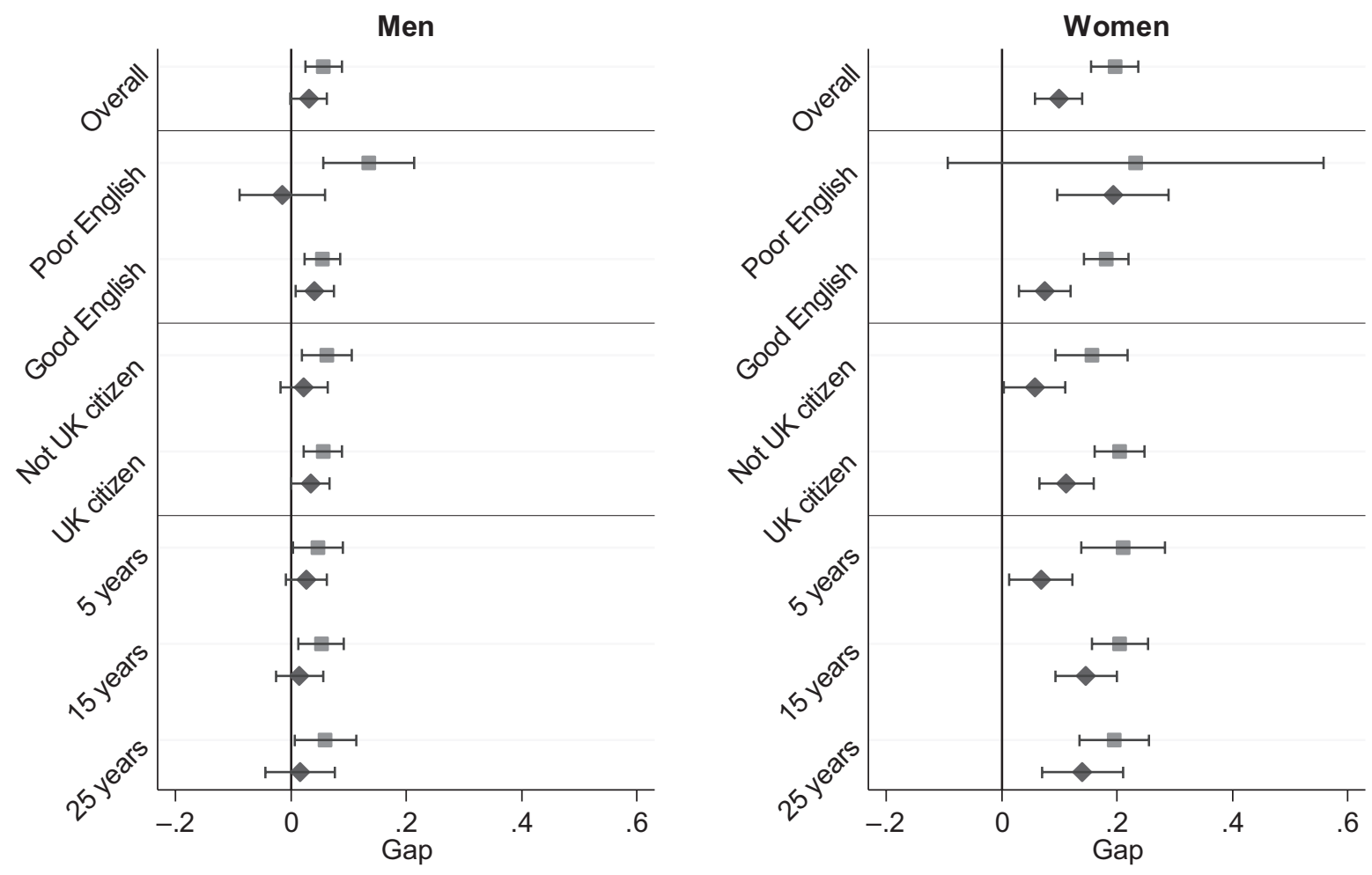

Post-secondary qual.: $\bullet$ Foreign $\square$ UK

Figure 3. Estimated effect of having foreign or UK post-secondary qualifications over post-secondary qualifications on employment for migrants.

public sector than the white British. This could be an indication of a strategy to protect against discrimination as well as selective recruitment efforts that modify migrant placement.

Table 1 shows the estimated gap in the probability of working on a job matching qualification and on a job for which respondents are over-qualified by gender and by sector. The analyses are restricted to those with UK citizenship or born in the UK, as they all have access to public sector jobs, and to those with post-secondary qualifications. Full regression results are shown in table A7 in the appendix.

Working in the public sector clearly provides shelter from disadvantage compared to similar white British. New EU, Indian, other Asian, Pakistani/Bangladeshi, black African and other male and female migrants, as well as Pakistani/Bangladeshi female UK-born, male Indian UK-born, and other white female migrants are all between 10 and 40p.p. more likely than their white British counterparts to be over-qualified when working in the private sector. In the public sector there are no such gaps with the exception of black African male and female migrants, UK-born black Caribbean women, UK-born black African men, Indian UK-born women, and female migrants from the new EU who are over-qualified in both public and private sector jobs. On average, UK-born minorities and especially migrants are more likely to find work matching their qualifications within the public sec- tor than in the private sector. While this could indicate less discrimination in the hiring process (Wood et al., 2009), it could also indicate higher selection, especially on credentials, in the public sector than in the private sector. Further, the average level of education is higher in the public sector (14 years of education on average compared to 13 years in the private sector) which would mechanically decrease the risk of over-qualification.

\subsection{Robustness}

Instead of studying the probability of working rather than not working, we restricted the analyses to those reporting they were looking actively for work in the last four weeks prior to the survey. This means the inactive or discouraged workers are excluded. When restricting outcomes to being employed rather than unemployed the differences among male white migrants are generally smaller particularly among lower qualified ethnic minority men-which indicates that they're on average lower employment probabilities are driven by higher inactivity. The same pattern with strong disadvantage for black Africans and black Caribbeans remains however. Among women as well the gaps are generally smaller, but remain substantial especially for Pakistani and Bangladeshi women, which indicates their higher non-employment is driven by higher unemployment as well as substantially higher inactivity rates. For other Asian UK-born women 

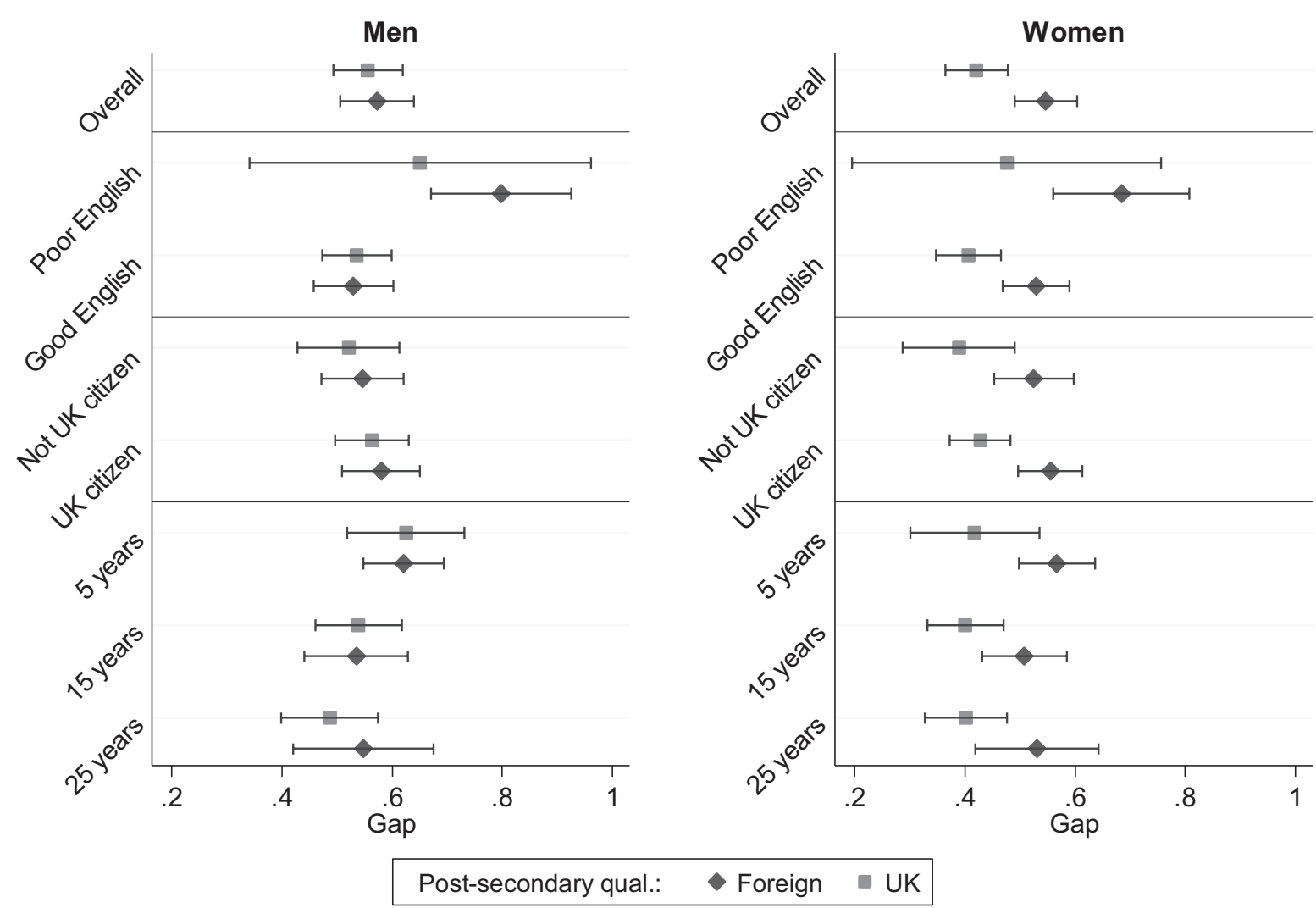

Figure 4. Estimated effect of having foreign or UK post-secondary qualifications over post-secondary qualifications on being over-qualified for migrants. Notes: Showing estimated returns to post-secondary qualifications compared to at most upper secondary for migrants, depending on whether obtained abroad or in the UK, in a baseline model controlling for urbanity, health, family situation, region and year, language skills, citizenship and years of residence (overall), as well as separate models interacting post-secondary qualifications with resp. language skills, citizenship, and years of residence (squared); effect in predicted probabilities estimated at grand margin.

the gap is almost wholly driven by inactivity however. As a second sensitivity test, we defined the qualification level in the occupation through the lowest mode of years of schooling rather than the average. This measure is more robust to highly qualified outliers or high variation within an occupation. We find that the gaps in overqualification remain very similar whether the mode or mean is used. The results are presented in table A8 and table $A 9$ in the supplementary material.

\section{Conclusion}

This article sets out to study the labour market integration and full use of the high human capital of migrant and ethnic minority workers in the UK. We show that tertiary qualifications do help to increase labour market outcomes of migrants and ethnic minorities and somewhat close their labour market gaps compared to the white British - the largest penalties are invariably experienced by the lowest qualified, not by the highest. Yet, important gaps remain even among highly qualified migrants and minorities. They are generally lowest for white second generation and worst for black Caribbean and black African first- and second-generation individuals. UK-born minorities and especially migrants are al- most never under-qualified compared to white British indicating that while majority members may be able to project higher productivity than their qualification implies, this is very unlikely for minorities and all but impossible for migrants.

How helpful are higher qualifications to migrants and second-generation minority members in the UK? Migrants face substantial difficulties in realizing good returns to their skills and human capital from abroad to the UK, which also represents a loss for the UK economy. Even foreign-obtained higher degrees make little difference for men, while for women there is a very small gain. Importantly, this discounting of qualifications seems to mainly occur among migrants whose productivity and skills may be less clear to employers to start with-more recent migrants, those with poorer language skills, and those without UK qualifications. This indicates that further integration in the host country-and further investments such as language skills-also help diminish the discounting of qualifications for migrants. This should be a policy priority in order to make the most of the highly-skilled migrants in the UK who already have invested perhaps considerable resources to obtain a University degree abroad.

Finally, we show that compared to the public sector, in the private sector, UK-born minorities as well as mi- 
Table 1. Estimated difference in predicted probability of being matched or over-qualified for job compared to white British majority, for those with post-secondary qualifications by gender and sector.

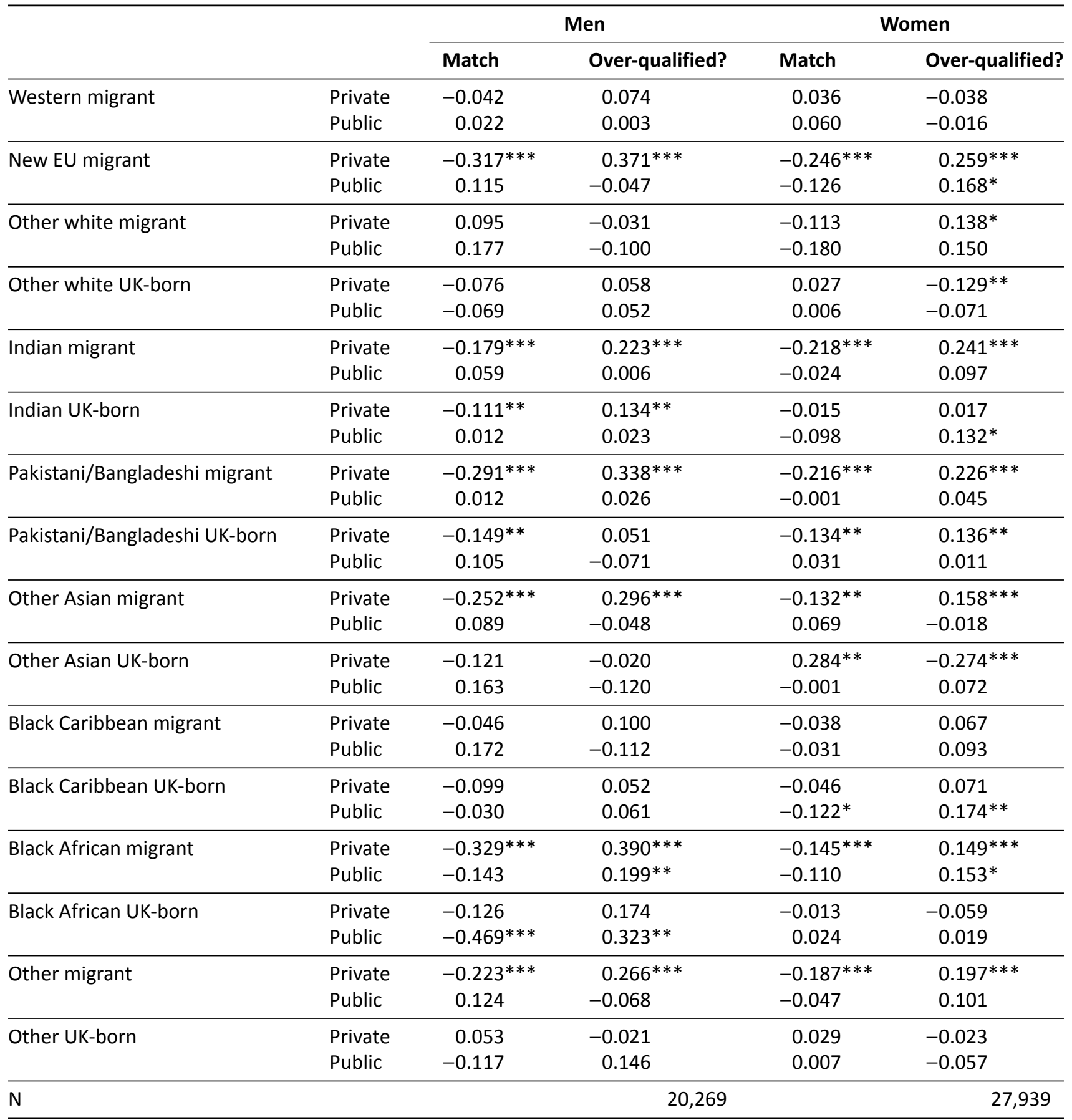

Notes: ${ }^{* *} \mathrm{p}<0.01,{ }^{* *} \mathrm{p}<0.05, * \mathrm{p}<0.1$; estimated gap in predicted probability of working a job matching own qualifications or being over-qualified compared to white British UK-born for those with at least post-secondary qualifications, estimated from logistic regression controlling for age (squared), urban, health, family situation, education, year of survey and region, weighted and with clustered standard errors; marginal effects by private/public sector are shown at the grand margin.

grants are less likely to work on jobs that match their qualifications fully. While there may be several reasons for this finding, it could indicate that part of this discounting is due to higher discrimination when hiring ethnic minorities - particularly present in the private sector. Future research should address the clearly better outcomes within the public sector.

\section{Acknowledgments}

This research and this thematic issue have been supported by funding from the European Commission (Grant number H2020 649255). 


\section{Conflict of Interests}

The authors declare no conflict of interests.

\section{References}

Algan, Y., Dustmann, C., Glitz, A., \& Manning, A. (2010). The economic situation of first and secondgeneration immigrants in France, Germany and the United Kingdom. The Economic Journal, 120(542), F4-F30.

Aydemir, A. (2011). Immigrant selection and short-term labor market outcomes by visa category. Journal of Population Economics, 24(2), 451-475.

Battu, H., \& Sloane, P. J. (2004). Over-education and ethnic minorities in Britain. The Manchester School, 72(4), 535-559.

Borjas, G. J., Kauppinen, I., \& Poutvaara, P. (2018). Self-selection of emigrants: Theory and evidence on stochastic dominance in observable and unobservable characteristics (NBER Working Paper no. 21649). Retrieved from http://www.nber.org/ papers/w21649.pdf

Cheung, S. Y. (2013). Ethno-religious minorities and labour market integration: Generational advancement or decline? Ethnic and Racial Studies, 37(1), 140-160.

Chiswick, B. R. (1978). The effect of Americanization on the earnings of foreign-born men. Journal of Political Economy, 86(5), 897-921.

Chiswick, C. U. (2009). The economic determinants of ethnic assimilation. Journal of Population Economics, 22, 859-880.

Damas de Matos, A., \& Liebig, T. (2014). The qualifications of immigrants and their value in the labour market: A comparison of Europe and the United States. In OECD/EU (Eds.), Matching economic migration with labour market needs (pp. 187-228). Paris: OECD Publishing.

Demireva, N., \& Kesler, C. (2011). The curse of inopportune transitions: The labour market behaviour of immigrants and natives in the UK. International Journal of Comparative Sociology, 52(4), 306-326.

Duleep, H. O., \& Regets, M. C. (1999). Immigrants and human-capital investment. The American Economic Review, 89(2), 186-191.

Dustmann, C., \& Theodoropoulos, N. (2010). Ethnic minority immigrants and their children in Britain. Ox- ford Economic Papers, 62(2), 209-233.

Green, F., \& McIntosh, S. (2007). Is there a genuine underutilisation of skills amongst the over-qualified? Applied Economics, 39(4), 427-439.

Huber, P., Landesmann, M., Robinson, C., \& Stehrer, R. (2010). Migrants' skills and productivity: A European perspective. National Institute Economic Review, 213(1), R20-R34.

Johnston, R., Khattab, N., \& Manley, D. (2015). East versus west? Over-qualification and earnings among the uk's european migrants. Journal of Ethnic and Migration Studies, 41(2), 196-218.

Knies, G. (2017). Understanding society: The UK household longitudinal study, Waves 1-7 (User Guide). Colchester: Institute for Social and Economic Research, University of Essex.

Li, Y., \& Heath, A. (2008). Minority ethnic men in british labour market (1972-2005). International Journal of Sociology and Social Policy, 28, 231-244.

Lindley, J. (2009). The over-education of UK immigrants and minority ethnic groups: Evidence from the Labour Force Survey. Economics of Education Review, 28(1), 80-89.

Modood, T. (2005). The educational attainments of ethnic minorities in Britain. In G. C. Loury, T. Modood, \& S. M. Teles (Eds.), Ethnicity, social mobility and public policy (pp. 288-308). Cambridge: Cambridge University Press.

Quintini, G. (2011). Over-qualified or under-skilled: A review of existing literature. Paris: OECD.

Rafferty, A. (2012). Ethnic penalties in graduate level over-education, unemployment and wages: Evidence from Britain. Work Employ. Soc., 26, 987-1006.

The Conservative and unionist Party (2017). Forward, together: Our plan for a stronger Britain and a prosperous future. Conservatives. Retrieved from www.conservatives.com/manifesto

Wood, M., Hales, J., Purdon, S., Sejersen, T., \& Hayllar, O. (2009). A test for racial discrimination in recruitment practice in British cities. London: Department for Work and Pensions.

Zwysen, W., \& Longhi, S. (2018). Employment and earning differences in the early career of ethnic minority British graduates: The importance of university career, parental background and area characteristics. Journal of Ethnic and Migration Studies, 44(1), 154-172.

\section{About the Authors}

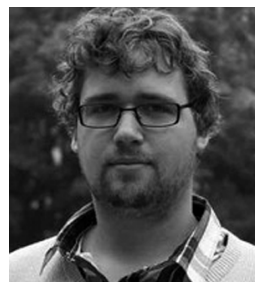

Wouter Zwysen (PhD) is a Senior Research Officer on the GEMM (Growth, Equal Opportunities, Migration and Markets) project at the University of Essex. He obtained his PhD from ISER, University of Essex in 2016. His research interests are socio-economic inequality in the labour market, labour market integration of migrants and minorities, and the importance of local area characteristics on the labour market. 


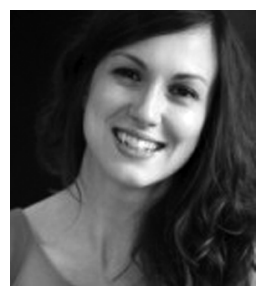

Neli Demireva (PhD) is a Senior Lecturer in Sociology at the University of Essex. Her research interests include migration, inter-ethnic ties, social cohesion, ethnic penalties and multiculturalism. She currently holds a BA grant on "Understanding the Ecology of Disadvantage: Betting Agents, Crime and the British Neighbourhood". From September 2015, she started working on the project "GEMM: Growth, Equal Opportunities, Migration and Markets" as part of the Horizon 2020 programme of the European Commission "EURO-2-2014: The European growth agenda Research and Innovation action 4: Migration, prosperity and growth". This project addresses the challenges and barriers that European countries face in managing the mobility of persons to realize competitiveness and growth. 
Annex

Table A1a. Descriptive statistics of sample for UK-born.

\begin{tabular}{lrrrrrrrr}
\hline & $\begin{array}{r}\text { White } \\
\text { British } \\
\text { UK-born }\end{array}$ & $\begin{array}{r}\text { Other } \\
\text { white } \\
\text { UK-born }\end{array}$ & Indian & $\begin{array}{r}\text { Pakistani/ } \\
\text { Bangladeshi }\end{array}$ & $\begin{array}{r}\text { Other } \\
\text { Asian }\end{array}$ & $\begin{array}{r}\text { Black } \\
\text { Caribbean }\end{array}$ & $\begin{array}{r}\text { black } \\
\text { African }\end{array}$ & $\begin{array}{c}\text { other } \\
\text { Employed }\end{array}$ \\
Unemployed & 0.80 & 0.73 & 0.78 & 0.60 & 0.76 & 0.71 & 0.79 & 0.70 \\
Inactive & 0.07 & 0.08 & 0.10 & 0.17 & 0.12 & 0.17 & 0.12 & 0.14 \\
Match qualifications (mean) & 0.13 & 0.20 & 0.13 & 0.23 & 0.12 & 0.12 & 0.09 & 0.16 \\
Over-qualified (mean) & 0.60 & 0.54 & 0.61 & 0.62 & 0.62 & 0.62 & 0.52 & 0.60 \\
Under-qualified (mean) & 0.22 & 0.25 & 0.05 & 0.09 & 0.08 & 0.11 & 0.04 & 0.15 \\
Match qualifications (mode) & 0.18 & 0.21 & 0.33 & 0.29 & 0.30 & 0.27 & 0.44 & 0.25 \\
Under-qualified (mode) & 0.58 & 0.57 & 0.61 & 0.59 & 0.71 & 0.62 & 0.56 & 0.59 \\
Over-qualified (mode) & 0.25 & 0.26 & 0.13 & 0.12 & 0.09 & 0.16 & 0.09 & 0.19 \\
Low qualifications & 0.17 & 0.17 & 0.26 & 0.29 & 0.20 & 0.22 & 0.35 & 0.22 \\
Middle qualifications & 0.62 & 0.61 & 0.46 & 0.60 & 0.45 & 0.55 & 0.30 & 0.52 \\
Tertiary qualifications & 0.12 & 0.11 & 0.12 & 0.09 & 0.07 & 0.17 & 0.14 & 0.15 \\
Degree obtained in the UK & 0.25 & 0.29 & 0.42 & 0.30 & 0.49 & 0.28 & 0.57 & 0.34 \\
dummy: urban & 0.99 & 0.95 & 1.00 & 0.98 & 0.99 & 0.97 & 0.89 & 0.98 \\
dummy: cohabiting & 0.74 & 0.56 & 0.98 & 0.99 & 0.93 & 1.00 & 0.98 & 0.95 \\
dummy: dependent child & 0.70 & 0.66 & 0.58 & 0.57 & 0.53 & 0.34 & 0.33 & 0.43 \\
dummy: poor health & 0.42 & 0.46 & 0.49 & 0.50 & 0.38 & 0.45 & 0.40 & 0.41 \\
dummy: UK citizen & 0.17 & 0.21 & 0.15 & 0.18 & 0.09 & 0.21 & 0.10 & 0.19 \\
dummy: English first language & 1.00 & 1.00 & 1.00 & 1.00 & 1.00 & 1.00 & 1.00 & 1.00 \\
N observations & 0.99 & 0.97 & 0.77 & 0.65 & 0.91 & 1.00 & 0.93 & 0.97 \\
N person-id & 136431 & 3930 & 2176 & 2877 & 435 & 2083 & 521 & 2834 \\
\hline & 34589 & 983 & 617 & 918 & 123 & 583 & 177 & 798 \\
\hline
\end{tabular}

Table A1b. Descriptive statistics of sample for migrants.

\begin{tabular}{|c|c|c|c|c|c|c|c|c|c|}
\hline & $\begin{array}{r}\mathrm{EU}-15 \\
+\mathrm{NO}\end{array}$ & $\begin{array}{r}\text { New } \\
\text { EU }\end{array}$ & $\begin{array}{l}\text { Other } \\
\text { white }\end{array}$ & Indian & $\begin{array}{c}\text { Pakistani/ } \\
\text { Bangladeshi }\end{array}$ & $\begin{array}{l}\text { Other } \\
\text { Asian }\end{array}$ & $\begin{array}{r}\text { Black } \\
\text { Caribbean }\end{array}$ & $\begin{array}{r}\text { Black } \\
\text { African }\end{array}$ & Other \\
\hline Employed & 0.81 & 0.81 & 0.80 & 0.75 & 0.47 & 0.76 & 0.71 & 0.67 & 0.67 \\
\hline Unemployed & 0.06 & 0.06 & 0.07 & 0.07 & 0.11 & 0.07 & 0.16 & 0.15 & 0.11 \\
\hline Inactive & 0.13 & 0.13 & 0.14 & 0.18 & 0.42 & 0.18 & 0.13 & 0.18 & 0.22 \\
\hline Match qualifications (mean) & 0.59 & 0.40 & 0.51 & 0.46 & 0.43 & 0.49 & 0.56 & 0.43 & 0.49 \\
\hline Over-qualified (mean) & 0.13 & 0.17 & 0.12 & 0.14 & 0.23 & 0.10 & 0.23 & 0.12 & 0.13 \\
\hline Under-qualified (mean) & 0.29 & 0.43 & 0.38 & 0.39 & 0.34 & 0.41 & 0.21 & 0.45 & 0.37 \\
\hline Match qualifications (mode) & 0.61 & 0.41 & 0.59 & 0.53 & 0.51 & 0.56 & 0.56 & 0.51 & 0.53 \\
\hline Under-qualified (mode) & 0.16 & 0.15 & 0.12 & 0.13 & 0.16 & 0.09 & 0.23 & 0.10 & 0.14 \\
\hline Over-qualified (mode) & 0.22 & 0.44 & 0.29 & 0.34 & 0.33 & 0.35 & 0.21 & 0.39 & 0.33 \\
\hline Low qualifications & 0.41 & 0.52 & 0.35 & 0.45 & 0.71 & 0.40 & 0.66 & 0.46 & 0.46 \\
\hline Middle qualifications & 0.14 & 0.10 & 0.23 & 0.11 & 0.04 & 0.12 & 0.14 & 0.17 & 0.11 \\
\hline Tertiary qualifications & 0.45 & 0.38 & 0.42 & 0.44 & 0.24 & 0.48 & 0.20 & 0.37 & 0.43 \\
\hline Degree obtained in the UK & 0.52 & 0.15 & 0.24 & 0.34 & 0.36 & 0.47 & 0.81 & 0.51 & 0.46 \\
\hline dummy: urban & 0.78 & 0.86 & 0.84 & 0.98 & 1.00 & 0.97 & 0.99 & 0.99 & 0.95 \\
\hline dummy: cohabiting & 0.69 & 0.77 & 0.79 & 0.85 & 0.85 & 0.78 & 0.42 & 0.59 & 0.70 \\
\hline dummy: dependent child & 0.43 & 0.54 & 0.53 & 0.54 & 0.75 & 0.54 & 0.40 & 0.62 & 0.58 \\
\hline dummy: poor health & 0.12 & 0.10 & 0.14 & 0.18 & 0.27 & 0.14 & 0.28 & 0.12 & 0.18 \\
\hline dummy: UK citizen & 0.73 & 0.62 & 0.78 & 0.82 & 0.87 & 0.80 & 0.89 & 0.79 & 0.81 \\
\hline dummy: English first language & 0.70 & 0.12 & 0.35 & 0.22 & 0.12 & 0.15 & 0.96 & 0.35 & 0.31 \\
\hline N observations & 3408 & 1942 & 686 & 3998 & 5320 & 2506 & 1201 & 3327 & 2098 \\
\hline N person-id & 997 & 585 & 212 & 1201 & 1731 & 737 & 388 & 1202 & 673 \\
\hline
\end{tabular}


Table A2. Probability of employment and match with qualifications by qualifications and gender. Source: Understanding Society 2009-2017, showing labour market outcomes by qualifications (low: at most upper secondary, middle: postsecondary non-tertiary, or high: tertiary) (Knies, 2017).

\begin{tabular}{|c|c|c|c|c|c|c|c|}
\hline \multirow[b]{2}{*}{ Qualification } & & \multicolumn{3}{|c|}{ Men } & \multicolumn{3}{|c|}{ Women } \\
\hline & & Low & Middle & High & Low & Middle & High \\
\hline \multirow[t]{3}{*}{ White British } & Employed & 0.80 & 0.92 & 0.94 & 0.70 & 0.86 & 0.90 \\
\hline & Under-qualified & 0.35 & 0.15 & 0.02 & 0.30 & 0.10 & 0.03 \\
\hline & Over-qualified & 0.01 & 0.35 & 0.47 & 0.01 & 0.41 & 0.41 \\
\hline \multirow[t]{3}{*}{ Western migrant } & Employed & 0.82 & 0.84 & 0.92 & 0.72 & 0.85 & 0.84 \\
\hline & Under-qualified & 0.26 & 0.07 & 0.00 & 0.32 & 0.08 & 0.00 \\
\hline & Over-qualified & 0.09 & 0.35 & 0.52 & 0.03 & 0.25 & 0.43 \\
\hline \multirow[t]{3}{*}{ New EU migrant } & Employed & 0.88 & 0.98 & 0.95 & 0.62 & 0.89 & 0.87 \\
\hline & Under-qualified & 0.41 & 0.00 & 0.00 & 0.23 & 0.03 & 0.00 \\
\hline & Over-qualified & 0.07 & 0.57 & 0.90 & 0.11 & 0.71 & 0.73 \\
\hline \multirow[t]{3}{*}{ Other white migrant } & Employed & 0.80 & 0.99 & 0.95 & 0.60 & 0.78 & 0.74 \\
\hline & Under-qualified & 0.33 & 0.02 & 0.00 & 0.28 & 0.10 & 0.00 \\
\hline & Over-qualified & 0.00 & 0.32 & 0.58 & 0.11 & 0.43 & 0.65 \\
\hline \multirow[t]{3}{*}{ Other white UK-born } & Employed & 0.67 & 0.91 & 0.89 & 0.65 & 0.83 & 0.89 \\
\hline & Under-qualified & 0.47 & 0.12 & 0.05 & 0.33 & 0.24 & 0.08 \\
\hline & Over-qualified & 0.05 & 0.42 & 0.51 & 0.01 & 0.37 & 0.28 \\
\hline \multirow[t]{3}{*}{ Indian migrant } & Employed & 0.85 & 0.85 & 0.96 & 0.59 & 0.81 & 0.69 \\
\hline & Under-qualified & 0.43 & 0.00 & 0.00 & 0.29 & 0.00 & 0.00 \\
\hline & Over-qualified & 0.04 & 0.63 & 0.63 & 0.04 & 0.46 & 0.66 \\
\hline \multirow[t]{3}{*}{ Indian UK-born } & Employed & 0.71 & 0.98 & 0.89 & 0.70 & 0.83 & 0.86 \\
\hline & Under-qualified & 0.13 & 0.00 & 0.02 & 0.15 & 0.01 & 0.00 \\
\hline & Over-qualified & 0.02 & 0.57 & 0.60 & 0.01 & 0.47 & 0.53 \\
\hline \multirow[t]{3}{*}{ Pakistani/Bangladeshi migrant } & Employed & 0.74 & 0.87 & 0.91 & 0.20 & 0.31 & 0.46 \\
\hline & Under-qualified & 0.46 & 0.00 & 0.00 & 0.38 & 0.00 & 0.00 \\
\hline & Over-qualified & 0.06 & 0.58 & 0.78 & 0.04 & 0.41 & 0.64 \\
\hline \multirow[t]{3}{*}{ Pakistani/Bangladeshi UK-born } & Employed & 0.73 & 0.85 & 0.89 & 0.39 & 0.62 & 0.70 \\
\hline & Under-qualified & 0.14 & 0.05 & 0.08 & 0.20 & 0.01 & 0.00 \\
\hline & Over-qualified & 0.01 & 0.54 & 0.50 & 0.01 & 0.51 & 0.62 \\
\hline \multirow[t]{3}{*}{ Other Asian migrant } & Employed & 0.86 & 0.93 & 0.95 & 0.55 & 0.85 & 0.79 \\
\hline & Under-qualified & 0.31 & 0.00 & 0.00 & 0.37 & 0.01 & 0.00 \\
\hline & Over-qualified & 0.14 & 0.72 & 0.67 & 0.02 & 0.51 & 0.53 \\
\hline \multirow[t]{3}{*}{ Other Asian UK-born } & Employed & 0.93 & 0.73 & 0.90 & 0.54 & 0.84 & 0.86 \\
\hline & Under-qualified & 0.12 & 0.00 & 0.12 & 0.14 & 0.00 & 0.00 \\
\hline & Over-qualified & 0.00 & 0.20 & 0.44 & 0.00 & 0.00 & 0.53 \\
\hline \multirow[t]{3}{*}{ Black Caribbean migrant } & Employed & 0.70 & 0.78 & 0.89 & 0.66 & 0.90 & 0.81 \\
\hline & Under-qualified & 0.52 & 0.00 & 0.00 & 0.24 & 0.04 & 0.00 \\
\hline & Over-qualified & 0.03 & 0.52 & 0.41 & 0.05 & 0.42 & 0.45 \\
\hline \multirow[t]{3}{*}{ Black Caribbean UK-born } & Employed & 0.64 & 0.72 & 0.78 & 0.60 & 0.79 & 0.87 \\
\hline & Under-qualified & 0.27 & 0.19 & 0.00 & 0.15 & 0.00 & 0.00 \\
\hline & Over-qualified & 0.01 & 0.43 & 0.54 & 0.02 & 0.49 & 0.56 \\
\hline \multirow[t]{3}{*}{ Black African migrant } & Employed & 0.70 & 0.85 & 0.84 & 0.49 & 0.76 & 0.79 \\
\hline & Under-qualified & 0.24 & 0.00 & 0.00 & 0.38 & 0.07 & 0.00 \\
\hline & Over-qualified & 0.04 & 0.75 & 0.75 & 0.05 & 0.50 & 0.63 \\
\hline
\end{tabular}


Table A2. (Cont.) Probability of employment and match with qualifications by qualifications and gender. Source: Understanding Society 2009-2017, showing labour market outcomes by qualifications (low: at most upper secondary, middle: post-secondary non-tertiary, or high: tertiary) (Knies, 2017).

\begin{tabular}{|c|c|c|c|c|c|c|c|}
\hline \multirow[b]{2}{*}{ Qualification } & & \multicolumn{3}{|c|}{ Men } & \multicolumn{3}{|c|}{ Women } \\
\hline & & Low & Middle & High & Low & Middle & High \\
\hline \multirow[t]{3}{*}{ Black African UK-born } & Employed & 0.57 & 0.89 & 0.90 & 0.56 & 0.82 & 0.90 \\
\hline & Under-qualified & 0.25 & 0.00 & 0.05 & 0.10 & 0.00 & 0.05 \\
\hline & Over-qualified & 0.05 & 0.21 & 0.79 & 0.00 & 0.73 & 0.34 \\
\hline \multirow[t]{3}{*}{ Other migrant } & Employed & 0.80 & 0.86 & 0.83 & 0.52 & 0.63 & 0.69 \\
\hline & Under-qualified & 0.34 & 0.00 & 0.00 & 0.29 & 0.04 & 0.00 \\
\hline & Over-qualified & 0.04 & 0.78 & 0.59 & 0.11 & 0.42 & 0.64 \\
\hline \multirow[t]{3}{*}{ Other UK-born } & Employed & 0.72 & 0.75 & 0.91 & 0.60 & 0.78 & 0.81 \\
\hline & Under-qualified & 0.26 & 0.04 & 0.00 & 0.30 & 0.07 & 0.05 \\
\hline & Over-qualified & 0.02 & 0.44 & 0.50 & 0.01 & 0.30 & 0.48 \\
\hline
\end{tabular}

Table A3. Binary logistic regression model (odds ratio) of employment, under- and over-qualification for men.

\begin{tabular}{|c|c|c|c|}
\hline Men & Employed & Under-qualified & Over-qualified \\
\hline Age & $\begin{array}{c}1.125^{* * *} \\
(0.013)\end{array}$ & $\begin{array}{c}1.022 \\
(0.015)\end{array}$ & $\begin{array}{c}0.900 * * * \\
(0.016)\end{array}$ \\
\hline Age2 & $\begin{array}{c}0.999 * * * \\
(0.000)\end{array}$ & $\begin{array}{c}1.000 \\
(0.000)\end{array}$ & $\begin{array}{c}1.001^{* * *} \\
(0.000)\end{array}$ \\
\hline $\begin{array}{l}\text { Qualifications (ref. low) } \\
\text { Middle qual. (ref. low) }\end{array}$ & $\begin{array}{c}2.161^{* * *} \\
(0.200)\end{array}$ & $\begin{array}{c}0.304 * * * \\
(0.028)\end{array}$ & $\begin{array}{c}39.700 * * * \\
(4.747)\end{array}$ \\
\hline High qual. (ref. low) & $\begin{array}{c}2.653^{* * *} \\
(0.177)\end{array}$ & $\begin{array}{c}0.043^{* * *} \\
(0.006)\end{array}$ & $\begin{array}{c}67.722 * * * \\
(7.420)\end{array}$ \\
\hline dummy: urban & $\begin{array}{c}0.728 * * * \\
(0.039)\end{array}$ & $\begin{array}{c}1.165^{* * *} \\
(0.068)\end{array}$ & $\begin{array}{c}0.958 \\
(0.067)\end{array}$ \\
\hline dummy: cohabit & $\begin{array}{c}3.139 * * * \\
(0.170)\end{array}$ & $\begin{array}{c}1.257^{* * *} \\
(0.080)\end{array}$ & $\begin{array}{c}0.792^{* * *} \\
(0.057)\end{array}$ \\
\hline dummy: dependent child & $\begin{array}{c}0.826 * * * \\
(0.047)\end{array}$ & $\begin{array}{c}0.979 \\
(0.056)\end{array}$ & $\begin{array}{c}1.040 \\
(0.066)\end{array}$ \\
\hline dummy: poor health & $\begin{array}{c}0.178 * * * \\
(0.007)\end{array}$ & $\begin{array}{c}1.066 \\
(0.057)\end{array}$ & $\begin{array}{c}1.068 \\
(0.079)\end{array}$ \\
\hline dummy: UK citizen & $\begin{array}{c}1.098 \\
(0.108) \\
\end{array}$ & $\begin{array}{c}1.035 \\
(0.125) \\
\end{array}$ & $\begin{array}{c}1.012 \\
(0.102) \\
\end{array}$ \\
\hline $\begin{array}{l}\text { Origin (ref. white British UH } \\
\text { Western migrant }\end{array}$ & $\begin{array}{c}1.177 \\
(0.317)\end{array}$ & $\begin{array}{l}0.673^{*} \\
(0.155)\end{array}$ & $\begin{array}{c}6.530 * * * \\
(3.098)\end{array}$ \\
\hline New EU migrant & $\begin{array}{c}1.466 \\
(0.350)\end{array}$ & $\begin{array}{l}1.627^{* *} \\
(0.374)\end{array}$ & $\begin{array}{c}4.873^{* * *} \\
(1.817)\end{array}$ \\
\hline Other white migrant & $\begin{array}{c}1.000 \\
(0.511)\end{array}$ & $\begin{array}{c}1.079 \\
(0.550)\end{array}$ & $\begin{array}{c}1.595 \\
(0.881)\end{array}$ \\
\hline Other white UK-born & $\begin{array}{c}0.622 * * * \\
(0.102)\end{array}$ & $\begin{array}{l}1.559 * \\
(0.369)\end{array}$ & $\begin{array}{c}3.657^{* *} \\
(1.988)\end{array}$ \\
\hline Indian migrant & $\begin{array}{c}1.102 \\
(0.206)\end{array}$ & $\begin{array}{c}1.176 \\
(0.254)\end{array}$ & $\begin{array}{c}3.705^{* * *} \\
(1.170)\end{array}$ \\
\hline
\end{tabular}


COGITATIO

Table A3. (Cont.) Binary logistic regression model (odds ratio) of employment, under- and over-qualification for men.

\begin{tabular}{|c|c|c|c|}
\hline Men & Employed & Under-qualified & Over-qualified \\
\hline Indian UK-born & $\begin{array}{c}0.644^{* *} \\
(0.144)\end{array}$ & $\begin{array}{c}0.393 * * \\
(0.182)\end{array}$ & $\begin{array}{c}0.970 \\
(0.564)\end{array}$ \\
\hline Pakistani/Bangladeshi migrant & $\begin{array}{c}0.603 * * * \\
(0.085)\end{array}$ & $\begin{array}{c}1.533^{* * *} \\
(0.244)\end{array}$ & $\begin{array}{c}5.294^{* * *} \\
(1.966)\end{array}$ \\
\hline Pakistani/Bangladeshi UK-born & $\begin{array}{c}0.654^{* *} \\
(0.141)\end{array}$ & $\begin{array}{c}0.413^{* *} \\
(0.145)\end{array}$ & $\begin{array}{c}0.725 \\
(0.339)\end{array}$ \\
\hline Other Asian migrant & $\begin{array}{c}1.254 \\
(0.334)\end{array}$ & $\begin{array}{c}0.839 \\
(0.261)\end{array}$ & $\begin{array}{c}12.783 * * * \\
(6.831)\end{array}$ \\
\hline Other Asian UK-born & $\begin{array}{c}2.758 * * \\
(1.374)\end{array}$ & $\begin{array}{c}0.318 \\
(0.228)\end{array}$ & $\begin{array}{c}0.824 \\
(0.325)\end{array}$ \\
\hline Black Caribbean migrant & $\begin{array}{l}0.664 * \\
(0.163)\end{array}$ & $\begin{array}{l}1.812^{*} \\
(0.606)\end{array}$ & $\begin{array}{l}2.528^{*} \\
(1.216)\end{array}$ \\
\hline Black Caribbean UK-born & $\begin{array}{c}0.463^{* * *} \\
(0.094)\end{array}$ & $\begin{array}{c}0.827 \\
(0.278)\end{array}$ & $\begin{array}{c}0.892 \\
(0.730)\end{array}$ \\
\hline Black African migrant & $\begin{array}{c}0.431 * * * \\
(0.082)\end{array}$ & $\begin{array}{c}0.707 \\
(0.235)\end{array}$ & $\begin{array}{c}2.836 * * * \\
(1.004)\end{array}$ \\
\hline Black African UK-born & $\begin{array}{c}0.262^{* *} \\
(0.141)\end{array}$ & $\begin{array}{c}0.896 \\
(0.994)\end{array}$ & $\begin{array}{c}2.832 \\
(2.173)\end{array}$ \\
\hline Other migrant & $\begin{array}{c}0.843 \\
(0.212)\end{array}$ & $\begin{array}{c}1.051 \\
(0.330)\end{array}$ & $\begin{array}{c}2.880 * * \\
(1.380)\end{array}$ \\
\hline Other UK-born & $\begin{array}{l}0.712 * \\
(0.132)\end{array}$ & $\begin{array}{c}0.898 \\
(0.240)\end{array}$ & $\begin{array}{c}0.883 \\
(0.602)\end{array}$ \\
\hline $\begin{array}{l}\text { Origin * qual (ref. white British } \\
\text { Western migrant * middle }\end{array}$ & $\begin{array}{c}0.324 * * * \\
(0.140)\end{array}$ & $\begin{array}{c}0.683 \\
(0.497)\end{array}$ & $\begin{array}{c}0.168 * * * \\
(0.099)\end{array}$ \\
\hline Western migrant * high & $\begin{array}{c}0.664 \\
(0.257)\end{array}$ & & $\begin{array}{c}0.190 * * * \\
(0.099)\end{array}$ \\
\hline New EU migrant $*$ middle & $\begin{array}{c}2.074 \\
(2.190)\end{array}$ & & $\begin{array}{c}0.501 \\
(0.331)\end{array}$ \\
\hline New EU migrant * high & $\begin{array}{c}0.634 \\
(0.289)\end{array}$ & & $\begin{array}{c}2.063 \\
(1.002)\end{array}$ \\
\hline Other white migrant $*$ middle & $\begin{array}{c}9.789 * \\
(11.921)\end{array}$ & $\begin{array}{l}0.109 * \\
(0.128)\end{array}$ & $\begin{array}{c}0.593 \\
(0.470)\end{array}$ \\
\hline Other white migrant $*$ high & $\begin{array}{c}1.333 \\
(1.243)\end{array}$ & & \\
\hline Other white UK-born * middle & $\begin{array}{c}2.124 \\
(1.402)\end{array}$ & $\begin{array}{c}0.653 \\
(0.421)\end{array}$ & $\begin{array}{c}0.310 \\
(0.239)\end{array}$ \\
\hline Other white UK-born * high & $\begin{array}{c}0.993 \\
(0.330)\end{array}$ & $\begin{array}{c}1.428 \\
(0.801)\end{array}$ & $\begin{array}{l}0.328^{*} \\
(0.198)\end{array}$ \\
\hline Indian migrant $*$ middle & $\begin{array}{l}0.442 * \\
(0.207)\end{array}$ & & $\begin{array}{c}0.964 \\
(0.534)\end{array}$ \\
\hline Indian migrant $*$ high & $\begin{array}{c}1.189 \\
(0.349)\end{array}$ & & $\begin{array}{l}0.536^{*} \\
(0.189)\end{array}$ \\
\hline Indian UK-born $*$ middle & $\begin{array}{c}9.884 * * * \\
(6.982)\end{array}$ & & $\begin{array}{c}2.345 \\
(1.727)\end{array}$ \\
\hline
\end{tabular}


Table A3. (Cont.) Binary logistic regression model (odds ratio) of employment, under- and over-qualification for men.

\begin{tabular}{|c|c|c|c|}
\hline Men & Employed & Under-qualified & Over-qualified \\
\hline Indian UK-born * high & $\begin{array}{c}1.122 \\
(0.402)\end{array}$ & $\begin{array}{c}2.565 \\
(2.871)\end{array}$ & $\begin{array}{c}1.404 \\
(0.865)\end{array}$ \\
\hline Pakistani/Bangladeshi migrant * middle & $\begin{array}{c}1.130 \\
(0.526)\end{array}$ & & $\begin{array}{c}0.424 \\
(0.301)\end{array}$ \\
\hline Pakistani/Bangladeshi migrant * high & $\begin{array}{c}1.203 \\
(0.359)\end{array}$ & & $\begin{array}{c}0.810 \\
(0.342)\end{array}$ \\
\hline Pakistani/Bangladeshi UK-born * middle & $\begin{array}{c}0.713 \\
(0.587)\end{array}$ & $\begin{array}{c}1.078 \\
(1.197)\end{array}$ & $\begin{array}{c}2.655 \\
(1.981)\end{array}$ \\
\hline Pakistani/Bangladeshi UK-born * high & $\begin{array}{c}0.886 \\
(0.341)\end{array}$ & $\begin{array}{c}11.885^{* * *} \\
(10.492)\end{array}$ & $\begin{array}{c}1.341 \\
(0.737)\end{array}$ \\
\hline Other Asian migrant $*$ middle & $\begin{array}{c}0.704 \\
(0.602)\end{array}$ & & $\begin{array}{c}0.393 \\
(0.323)\end{array}$ \\
\hline Other Asian migrant * high & $\begin{array}{c}0.879 \\
(0.334)\end{array}$ & & $\begin{array}{c}0.188 * * * \\
(0.111)\end{array}$ \\
\hline Other Asian UK-born * middle & $\begin{array}{c}0.095^{* * *} \\
(0.054)\end{array}$ & & $\begin{array}{c}0.457^{*} \\
(0.198)\end{array}$ \\
\hline Other Asian UK-born * high & $\begin{array}{c}0.247^{* *} \\
(0.151)\end{array}$ & $\begin{array}{c}23.008 * * * \\
(23.576)\end{array}$ & \\
\hline Black Caribbean migrant $*$ middle & $\begin{array}{c}0.867 \\
(0.740)\end{array}$ & & $\begin{array}{c}0.828 \\
(0.757)\end{array}$ \\
\hline Black Caribbean migrant * high & $\begin{array}{c}0.816 \\
(0.444)\end{array}$ & & $\begin{array}{l}0.370 * \\
(0.221)\end{array}$ \\
\hline Black Caribbean UK-born * middle & $\begin{array}{c}0.576 \\
(0.232)\end{array}$ & $\begin{array}{c}1.851 \\
(1.228)\end{array}$ & $\begin{array}{c}1.499 \\
(1.395)\end{array}$ \\
\hline Black Caribbean UK-born * high & $\begin{array}{c}0.653 \\
(0.307)\end{array}$ & & $\begin{array}{c}1.378 \\
(1.242)\end{array}$ \\
\hline Black African migrant * middle & $\begin{array}{c}1.022 \\
(0.337)\end{array}$ & & $\begin{array}{c}2.207 \\
(1.075)\end{array}$ \\
\hline Black African migrant * high & $\begin{array}{c}0.676 \\
(0.188)\end{array}$ & & $\begin{array}{c}1.226 \\
(0.553)\end{array}$ \\
\hline Black African UK-born * middle & $\begin{array}{c}3.485 \\
(3.867)\end{array}$ & & $\begin{array}{c}0.143 \\
(0.178)\end{array}$ \\
\hline Black African UK-born * high & $\begin{array}{c}3.155 \\
(2.321)\end{array}$ & $\begin{array}{c}3.380 \\
(5.101)\end{array}$ & $\begin{array}{c}1.331 \\
(1.164)\end{array}$ \\
\hline Other migrant $*$ middle & $\begin{array}{c}0.752 \\
(0.392)\end{array}$ & & $\begin{array}{c}2.228 \\
(1.635)\end{array}$ \\
\hline Other migrant $*$ high & $\begin{array}{c}0.364^{* * *} \\
(0.134)\end{array}$ & & $\begin{array}{c}0.566 \\
(0.313)\end{array}$ \\
\hline Other UK-born * middle & $\begin{array}{c}0.506 \\
(0.293)\end{array}$ & $\begin{array}{c}0.370 \\
(0.270)\end{array}$ & $\begin{array}{c}1.426 \\
(1.226)\end{array}$ \\
\hline Other UK-born * high & $\begin{array}{c}1.088 \\
(0.462)\end{array}$ & $\begin{array}{c}0.184 \\
(0.193)\end{array}$ & $\begin{array}{c}1.163 \\
(0.846)\end{array}$ \\
\hline Year of survey dummies & Yes & Yes & Yes \\
\hline Government office region dummies & Yes & Yes & Yes \\
\hline
\end{tabular}




\section{COGITATIO}

Table A3. (Cont.) Binary logistic regression model (odds ratio) of employment, under- and over-qualification for men.

\begin{tabular}{lccc}
\hline Men & Employed & Under-qualified & Over-qualified \\
\hline Constant & $0.319 * * *$ & $0.109 * * *$ & $0.221^{* * *}$ \\
& $(0.082)$ & $(0.035)$ & $(0.084)$ \\
\hline Observations & 77,430 & 52,677 & 57,217
\end{tabular}

Notes: ${ }^{* * *} \mathrm{p}<0.01,{ }^{* *} \mathrm{p}<0.05,{ }^{*} \mathrm{p}<0.1$; estimated odds ratio of being employed, having lower than average qualification, or having higher than average qualifications for those aged 16-64, not in education/training or retired; weighted binary logistic regression clustered by person-id; controlling for age, education, urbanity, cohabiting, dependent child, poor health, f.e. for survey year and region.

Table A4. Binary logistic regression model (odds ratio) of employment, under- and over-qualification for women.

\begin{tabular}{|c|c|c|c|}
\hline Women & Employed & Under-qualified & Over-qualified \\
\hline Age & $\begin{array}{c}1.159 * * * \\
(0.012)\end{array}$ & $\begin{array}{c}1.022 \\
(0.015)\end{array}$ & $\begin{array}{c}0.873 * * * \\
(0.015)\end{array}$ \\
\hline Age2 & $\begin{array}{c}0.998 * * * \\
(0.000)\end{array}$ & $\begin{array}{c}1.000 \\
(0.000)\end{array}$ & $\begin{array}{c}1.001^{* * *} \\
(0.000)\end{array}$ \\
\hline $\begin{array}{l}\text { Qualifications (ref. low) } \\
\text { Middle qual. (ref. low) }\end{array}$ & $\begin{array}{c}2.436 * * * \\
(0.152)\end{array}$ & $\begin{array}{c}0.235^{* * *} \\
(0.021)\end{array}$ & $\begin{array}{c}90.253^{* * *} \\
(11.929)\end{array}$ \\
\hline High qual. (ref. low) & $\begin{array}{c}3.100 * * * \\
(0.159)\end{array}$ & $\begin{array}{c}0.064^{* * *} \\
(0.007)\end{array}$ & $\begin{array}{c}87.941 * * * \\
(11.055)\end{array}$ \\
\hline dummy: urban & $\begin{array}{c}0.899 * * \\
(0.038)\end{array}$ & $\begin{array}{c}0.943 \\
(0.056)\end{array}$ & $\begin{array}{c}0.884^{* *} \\
(0.054)\end{array}$ \\
\hline dummy: cohabit & $\begin{array}{c}1.295^{* * *} \\
(0.046)\end{array}$ & $\begin{array}{c}1.031 \\
(0.056)\end{array}$ & $\begin{array}{c}0.852^{* * *} \\
(0.046)\end{array}$ \\
\hline dummy: dependent child & $\begin{array}{c}0.344^{* * *} \\
(0.014)\end{array}$ & $\begin{array}{l}1.116^{*} \\
(0.063)\end{array}$ & $\begin{array}{c}1.060 \\
(0.058)\end{array}$ \\
\hline dummy: poor health & $\begin{array}{c}0.215^{* * *} \\
(0.007)\end{array}$ & $\begin{array}{c}1.208^{* * *} \\
(0.064)\end{array}$ & $\begin{array}{c}1.456 * * * \\
(0.094)\end{array}$ \\
\hline dummy: UK citizen & $\begin{array}{c}1.262^{* * *} \\
(0.090)\end{array}$ & $\begin{array}{c}0.863 \\
(0.109)\end{array}$ & $\begin{array}{l}0.812 * * \\
(0.071)\end{array}$ \\
\hline $\begin{array}{l}\text { Origin (ref. white British UK-borr } \\
\text { Western migrant }\end{array}$ & $\begin{array}{c}1.160 \\
(0.195)\end{array}$ & $\begin{array}{c}1.194 \\
(0.240)\end{array}$ & $\begin{array}{l}2.885^{*} \\
(1.829)\end{array}$ \\
\hline New EU migrant & $\begin{array}{c}0.748 \\
(0.142)\end{array}$ & $\begin{array}{c}0.829 \\
(0.235)\end{array}$ & $\begin{array}{c}12.226^{* * *} \\
(4.805)\end{array}$ \\
\hline Other white migrant & $\begin{array}{c}0.827 \\
(0.310)\end{array}$ & $\begin{array}{c}1.226 \\
(0.583)\end{array}$ & $\begin{array}{c}12.814 * * * \\
(9.139)\end{array}$ \\
\hline Other white UK-born & $\begin{array}{c}0.867 \\
(0.134)\end{array}$ & $\begin{array}{c}1.255 \\
(0.340)\end{array}$ & $\begin{array}{c}1.001 \\
(1.028)\end{array}$ \\
\hline Indian migrant & $\begin{array}{c}0.659 * * \\
(0.115)\end{array}$ & $\begin{array}{c}0.852 \\
(0.242)\end{array}$ & $\begin{array}{c}5.103 * * * \\
(2.632)\end{array}$ \\
\hline Indian UK-born & $\begin{array}{c}1.142 \\
(0.228)\end{array}$ & $\begin{array}{c}0.512 * * \\
(0.158)\end{array}$ & $\begin{array}{c}0.507 \\
(0.513)\end{array}$ \\
\hline Pakistani/Bangladeshi migrant & $\begin{array}{c}0.125^{* * *} \\
(0.018)\end{array}$ & $\begin{array}{l}1.650 * \\
(0.496)\end{array}$ & $\begin{array}{c}4.208 * * \\
(2.731)\end{array}$ \\
\hline Pakistani/Bangladeshi UK-born & $\begin{array}{c}0.277^{* * *} \\
(0.062)\end{array}$ & $\begin{array}{c}0.961 \\
(0.285)\end{array}$ & $\begin{array}{c}0.558 \\
(0.363)\end{array}$ \\
\hline
\end{tabular}




\section{COgitatio}

Table A4. (Cont.) Binary logistic regression model (odds ratio) of employment, under- and over-qualification for women.

\begin{tabular}{|c|c|c|c|}
\hline Women & Employed & Under-qualified & Over-qualified \\
\hline Other Asian migrant & $\begin{array}{c}0.514^{* * *} \\
(0.100)\end{array}$ & $\begin{array}{c}1.449 \\
(0.399)\end{array}$ & $\begin{array}{c}2.452 * * \\
(1.074)\end{array}$ \\
\hline Other Asian UK-born & $\begin{array}{c}0.571 \\
(0.284)\end{array}$ & $\begin{array}{c}0.509 \\
(0.512)\end{array}$ & $\begin{array}{c}1.144 \\
(0.605)\end{array}$ \\
\hline Black Caribbean migrant & $\begin{array}{c}1.346 \\
(0.276)\end{array}$ & $\begin{array}{l}0.577^{*} \\
(0.190)\end{array}$ & $\begin{array}{c}6.837^{* * *} \\
(4.343)\end{array}$ \\
\hline Black Caribbean UK-born & $\begin{array}{c}0.869 \\
(0.175)\end{array}$ & $\begin{array}{c}0.474 * * * \\
(0.131)\end{array}$ & $\begin{array}{c}2.320 \\
(1.354)\end{array}$ \\
\hline Black African migrant & $\begin{array}{c}0.523 * * * \\
(0.075)\end{array}$ & $\begin{array}{c}1.547^{* *} \\
(0.335)\end{array}$ & $\begin{array}{c}6.358 * * * \\
(2.933)\end{array}$ \\
\hline Black African UK-born & $\begin{array}{c}0.623 \\
(0.202)\end{array}$ & $\begin{array}{c}0.424 \\
(0.292)\end{array}$ & $\begin{array}{c}0.624 \\
(0.250)\end{array}$ \\
\hline Other migrant & $\begin{array}{c}0.548 * * \\
(0.128)\end{array}$ & $\begin{array}{c}1.054 \\
(0.353)\end{array}$ & $\begin{array}{c}11.955^{* * *} \\
(6.272)\end{array}$ \\
\hline Other UK-born & $\begin{array}{l}0.743^{*} \\
(0.124)\end{array}$ & $\begin{array}{c}1.336 \\
(0.346)\end{array}$ & $\begin{array}{c}0.757 \\
(0.707)\end{array}$ \\
\hline $\begin{array}{l}\text { Origin * qual (ref. white British low qual.) } \\
\text { Western migrant * middle }\end{array}$ & $\begin{array}{c}0.769 \\
(0.247)\end{array}$ & $\begin{array}{c}0.619 \\
(0.335)\end{array}$ & $\begin{array}{c}0.180 * * \\
(0.127)\end{array}$ \\
\hline Western migrant * high & $\begin{array}{c}0.487 * * * \\
(0.116)\end{array}$ & & $\begin{array}{c}0.380 \\
(0.249)\end{array}$ \\
\hline New EU migrant $*$ middle & $\begin{array}{c}1.730 \\
(0.776)\end{array}$ & $\begin{array}{c}0.452 \\
(0.356)\end{array}$ & $\begin{array}{c}0.240 * * * \\
(0.122)\end{array}$ \\
\hline New EU migrant * high & $\begin{array}{c}1.024 \\
(0.305)\end{array}$ & & $\begin{array}{c}0.277^{* * *} \\
(0.129)\end{array}$ \\
\hline Other white migrant $*$ middle & $\begin{array}{c}0.818 \\
(0.472)\end{array}$ & $\begin{array}{c}0.846 \\
(0.683)\end{array}$ & $\begin{array}{c}0.079 * * * \\
(0.067)\end{array}$ \\
\hline Other white migrant $*$ high & $\begin{array}{l}0.394 * * \\
(0.185)\end{array}$ & & $\begin{array}{l}0.218^{*} \\
(0.174)\end{array}$ \\
\hline Other white UK-born * middle & $\begin{array}{c}0.985 \\
(0.456)\end{array}$ & $\begin{array}{c}2.075 \\
(1.266)\end{array}$ & $\begin{array}{c}0.873 \\
(0.948)\end{array}$ \\
\hline Other white UK-born * high & $\begin{array}{c}1.251 \\
(0.434)\end{array}$ & $\begin{array}{l}2.396 * \\
(1.199)\end{array}$ & $\begin{array}{c}0.582 \\
(0.613)\end{array}$ \\
\hline Indian migrant $*$ middle & $\begin{array}{c}1.218 \\
(0.518)\end{array}$ & & $\begin{array}{l}0.250^{* *} \\
(0.151)\end{array}$ \\
\hline Indian migrant * high & $\begin{array}{c}0.434^{* * *} \\
(0.104)\end{array}$ & & $\begin{array}{c}0.530 \\
(0.293)\end{array}$ \\
\hline Indian UK-born * middle & $\begin{array}{c}1.006 \\
(0.483)\end{array}$ & $\begin{array}{c}0.280 \\
(0.303)\end{array}$ & $\begin{array}{c}2.500 \\
(2.700)\end{array}$ \\
\hline Indian UK-born * high & $\begin{array}{c}0.612 \\
(0.192)\end{array}$ & & $\begin{array}{c}2.557 \\
(2.651)\end{array}$ \\
\hline Pakistani/Bangladeshi migrant * middle & $\begin{array}{c}0.627 \\
(0.247)\end{array}$ & & $\begin{array}{l}0.219 * \\
(0.191)\end{array}$ \\
\hline Pakistani/Bangladeshi migrant * high & $\begin{array}{c}0.967 \\
(0.256)\end{array}$ & & $\begin{array}{c}0.581 \\
(0.421)\end{array}$ \\
\hline
\end{tabular}




\section{COGITATIO}

Table A4. (Cont.) Binary logistic regression model (odds ratio) of employment, under- and over-qualification for women.

\begin{tabular}{|c|c|c|c|}
\hline Women & Employed & Under-qualified & Over-qualified \\
\hline Pakistani/Bangladeshi UK-born * middle & $\begin{array}{c}0.914 \\
(0.394)\end{array}$ & $\begin{array}{c}0.123^{* *} \\
(0.131)\end{array}$ & $\begin{array}{c}1.979 \\
(1.503)\end{array}$ \\
\hline Pakistani/Bangladeshi UK-born * high & $\begin{array}{c}1.016 \\
(0.321)\end{array}$ & & $\begin{array}{c}2.919 \\
(2.085)\end{array}$ \\
\hline Other Asian migrant * middle & $\begin{array}{c}1.826 \\
(0.729)\end{array}$ & $\begin{array}{c}0.100 * * \\
(0.106)\end{array}$ & $\begin{array}{c}0.595 \\
(0.334)\end{array}$ \\
\hline Other Asian Migrant * high & $\begin{array}{c}0.775 \\
(0.225)\end{array}$ & & $\begin{array}{c}0.663 \\
(0.325)\end{array}$ \\
\hline Other Asian UK-born * middle & $\begin{array}{c}1.170 \\
(1.033)\end{array}$ & & \\
\hline Other Asian UK-born * high & $\begin{array}{c}0.971 \\
(0.596)\end{array}$ & & \\
\hline Black Caribbean migrant $*$ middle & $\begin{array}{c}1.604 \\
(0.719)\end{array}$ & $\begin{array}{c}0.531 \\
(0.486)\end{array}$ & $\begin{array}{c}0.167^{* *} \\
(0.123)\end{array}$ \\
\hline Black Caribbean migrant * high & $\begin{array}{c}0.557 \\
(0.241)\end{array}$ & & $\begin{array}{c}0.169 * * \\
(0.126)\end{array}$ \\
\hline Black Caribbean UK-born * middle & $\begin{array}{c}1.006 \\
(0.362)\end{array}$ & $\begin{array}{c}0.042 * * * \\
(0.045)\end{array}$ & $\begin{array}{c}0.574 \\
(0.378)\end{array}$ \\
\hline Black Caribbean UK-born * high & $\begin{array}{c}1.153 \\
(0.365)\end{array}$ & & $\begin{array}{c}0.802 \\
(0.503)\end{array}$ \\
\hline Black African migrant * middle & $\begin{array}{c}1.445 \\
(0.375)\end{array}$ & $\begin{array}{c}0.518 \\
(0.422)\end{array}$ & $\begin{array}{c}0.209 * * * \\
(0.116)\end{array}$ \\
\hline Black African migrant * high & $\begin{array}{c}0.962 \\
(0.223)\end{array}$ & & $\begin{array}{c}0.350 * * \\
(0.185)\end{array}$ \\
\hline Black African UK-born * middle & $\begin{array}{c}1.775 \\
(0.967)\end{array}$ & & $\begin{array}{c}5.678 * * \\
(4.341)\end{array}$ \\
\hline Black African UK-born * high & $\begin{array}{c}1.956 \\
(0.956)\end{array}$ & $\begin{array}{c}5.557 \\
(6.729)\end{array}$ & \\
\hline Other migrant $*$ middle & $\begin{array}{c}0.654 \\
(0.242)\end{array}$ & $\begin{array}{c}0.357 \\
(0.308)\end{array}$ & $\begin{array}{c}0.082^{* * *} \\
(0.053)\end{array}$ \\
\hline Other migrant * high & $\begin{array}{c}0.500 * * \\
(0.175)\end{array}$ & & $\begin{array}{c}0.204^{* * *} \\
(0.123)\end{array}$ \\
\hline Other UK-born * middle & $\begin{array}{c}1.171 \\
(0.476)\end{array}$ & $\begin{array}{c}0.639 \\
(0.503)\end{array}$ & $\begin{array}{c}0.649 \\
(0.647)\end{array}$ \\
\hline Other UK-born * high & $\begin{array}{c}0.709 \\
(0.192)\end{array}$ & $\begin{array}{c}1.602 \\
(1.112)\end{array}$ & $\begin{array}{c}1.591 \\
(1.528)\end{array}$ \\
\hline Year of survey dummies & Yes & Yes & Yes \\
\hline Government office region dummies & Yes & Yes & Yes \\
\hline Constant & $\begin{array}{c}0.212^{* * *} \\
(0.045)\end{array}$ & $\begin{array}{c}0.102 * * * \\
(0.033)\end{array}$ & $\begin{array}{c}0.236 * * * \\
(0.086)\end{array}$ \\
\hline Observations & 98,343 & 59,389 & 64,298 \\
\hline
\end{tabular}

Notes: ${ }^{* * *} p<0.01,{ }^{* *} \mathrm{p}<0.05,{ }^{*} \mathrm{p}<0.1$; estimated odds ratio of being employed, having lower than average qualification, or having higher than average qualifications for those aged 16-64, not in education/training or retired; weighted binary logistic regression clustered by person-id; controlling for age, education, urbanity, cohabiting, dependent child, poor health, f.e. for survey year and region. 
Table A5. Binary logistic regression model with sequential interactions of post-secondary qualifications for men.

\begin{tabular}{|c|c|c|c|c|c|c|c|c|}
\hline & \multicolumn{4}{|c|}{ Employment } & \multicolumn{4}{|c|}{ Over-qualification } \\
\hline & Base & *English & $\begin{array}{c}\text { *UK } \\
\text { citizen }\end{array}$ & $\begin{array}{l}* \text { Years of } \\
\text { residence }\end{array}$ & Base & *English & $\begin{array}{c}\text { *UK } \\
\text { citizen }\end{array}$ & $\begin{array}{l}* \text { Years of } \\
\text { residence }\end{array}$ \\
\hline Age & $\begin{array}{c}1.164 * * * \\
(0.056)\end{array}$ & $\begin{array}{c}1.164 * * * \\
(0.056)\end{array}$ & $\begin{array}{c}1.163^{* * *} \\
(0.056)\end{array}$ & $\begin{array}{c}1.184^{* * *} \\
(0.061)\end{array}$ & $\begin{array}{c}1.024 \\
(0.059)\end{array}$ & $\begin{array}{c}1.030 \\
(0.059)\end{array}$ & $\begin{array}{c}1.024 \\
(0.059)\end{array}$ & $\begin{array}{c}1.056 \\
(0.063)\end{array}$ \\
\hline Age2 & $\begin{array}{c}0.998 * * * \\
(0.001)\end{array}$ & $\begin{array}{c}0.998 * * * \\
(0.001)\end{array}$ & $\begin{array}{c}0.998 * * * \\
(0.001)\end{array}$ & $\begin{array}{c}0.998 * * * \\
(0.001)\end{array}$ & $\begin{array}{c}1.000 \\
(0.001)\end{array}$ & $\begin{array}{c}1.000 \\
(0.001)\end{array}$ & $\begin{array}{c}1.000 \\
(0.001)\end{array}$ & $\begin{array}{c}0.999 \\
(0.001)\end{array}$ \\
\hline dummy: urban & $\begin{array}{c}0.692 \\
(0.215)\end{array}$ & $\begin{array}{c}0.697 \\
(0.216)\end{array}$ & $\begin{array}{c}0.694 \\
(0.216)\end{array}$ & $\begin{array}{c}0.683 \\
(0.210)\end{array}$ & $\begin{array}{c}0.944 \\
(0.270)\end{array}$ & $\begin{array}{c}0.950 \\
(0.271)\end{array}$ & $\begin{array}{c}0.945 \\
(0.269)\end{array}$ & $\begin{array}{c}0.954 \\
(0.273)\end{array}$ \\
\hline dummy: cohabit & $\begin{array}{c}3.262 * * * \\
(0.698)\end{array}$ & $\begin{array}{c}3.212^{* * *} \\
(0.688)\end{array}$ & $\begin{array}{c}3.260 * * * \\
(0.697)\end{array}$ & $\begin{array}{c}3.275^{* * *} \\
(0.726)\end{array}$ & $\begin{array}{l}0.665^{*} \\
(0.143)\end{array}$ & $\begin{array}{l}0.679 * \\
(0.144)\end{array}$ & $\begin{array}{l}0.666^{*} \\
(0.143)\end{array}$ & $\begin{array}{l}0.668 * \\
(0.144)\end{array}$ \\
\hline $\begin{array}{l}\text { dummy: dependent } \\
\text { child }\end{array}$ & $\begin{array}{l}0.743^{*} \\
(0.119)\end{array}$ & $\begin{array}{l}0.746^{*} \\
(0.120)\end{array}$ & $\begin{array}{l}0.743^{*} \\
(0.119)\end{array}$ & $\begin{array}{l}0.761^{*} \\
(0.125)\end{array}$ & $\begin{array}{c}1.190 \\
(0.193)\end{array}$ & $\begin{array}{c}1.195 \\
(0.194)\end{array}$ & $\begin{array}{c}1.190 \\
(0.193)\end{array}$ & $\begin{array}{c}1.208 \\
(0.196)\end{array}$ \\
\hline dummy: poor health & $\begin{array}{c}0.198 * * * \\
(0.028)\end{array}$ & $\begin{array}{c}0.198 * * * \\
(0.028)\end{array}$ & $\begin{array}{c}0.198 * * * \\
(0.028)\end{array}$ & $\begin{array}{c}0.202 * * * \\
(0.029)\end{array}$ & $\begin{array}{c}1.088 \\
(0.196)\end{array}$ & $\begin{array}{c}1.051 \\
(0.192)\end{array}$ & $\begin{array}{c}1.091 \\
(0.198)\end{array}$ & $\begin{array}{c}1.095 \\
(0.199)\end{array}$ \\
\hline dummy: UK citizen & $\begin{array}{c}0.972 \\
(0.117)\end{array}$ & $\begin{array}{c}0.973 \\
(0.118)\end{array}$ & $\begin{array}{c}0.951 \\
(0.143)\end{array}$ & $\begin{array}{c}1.032 \\
(0.130)\end{array}$ & $\begin{array}{c}1.151 \\
(0.132)\end{array}$ & $\begin{array}{c}1.141 \\
(0.132)\end{array}$ & $\begin{array}{c}1.014 \\
(0.241)\end{array}$ & $\begin{array}{c}1.206 \\
(0.142)\end{array}$ \\
\hline $\begin{array}{l}\text { Qualifications (ref. } \\
\text { at most secondary) } \\
\text { foreign post- } \\
\text { secondary qual. }\end{array}$ & $\begin{array}{l}1.366^{*} \\
(0.223)\end{array}$ & $\begin{array}{c}1.571 * * \\
(0.295)\end{array}$ & $\begin{array}{c}1.264 \\
(0.265)\end{array}$ & $\begin{array}{c}1.624 \\
(0.560)\end{array}$ & $\begin{array}{c}27.165^{* * *} \\
(7.137)\end{array}$ & $\begin{array}{c}19.667 * * * \\
(5.435)\end{array}$ & $\begin{array}{c}24.292^{* * *} \\
(6.543)\end{array}$ & $\begin{array}{c}39.037^{* * *} \\
(18.080)\end{array}$ \\
\hline $\begin{array}{l}\text { UK-based post- } \\
\text { secondary qual. }\end{array}$ & $\begin{array}{c}1.883 * * * \\
(0.355)\end{array}$ & $\begin{array}{c}1.886 * * * \\
(0.365)\end{array}$ & $\begin{array}{c}2.060 * * \\
(0.579)\end{array}$ & $\begin{array}{c}1.898 \\
(0.888)\end{array}$ & $\begin{array}{c}25.248 * * * \\
(6.668)\end{array}$ & $\begin{array}{c}20.181 * * * \\
(5.197)\end{array}$ & $\begin{array}{c}21.802 * * * \\
(6.711)\end{array}$ & $\begin{array}{c}36.096 * * * \\
(19.620) \\
\end{array}$ \\
\hline English problems & $\begin{array}{c}0.571^{* * *} \\
(0.083)\end{array}$ & $\begin{array}{c}0.637^{* * *} \\
(0.108)\end{array}$ & $\begin{array}{c}0.572 * * * \\
(0.083)\end{array}$ & $\begin{array}{c}0.538 * * * \\
(0.079)\end{array}$ & $\begin{array}{c}1.385 \\
(0.307)\end{array}$ & $\begin{array}{c}0.595 \\
(0.220)\end{array}$ & $\begin{array}{c}1.375 \\
(0.302)\end{array}$ & $\begin{array}{c}1.319 \\
(0.295)\end{array}$ \\
\hline $\begin{array}{l}\text { Foreign post- } \\
\text { secondary }{ }^{*} \text { English } \\
\text { problems }\end{array}$ & & $\begin{array}{l}0.570 * \\
(0.183)\end{array}$ & & & & $\begin{array}{c}6.228^{* * *} \\
(3.945)\end{array}$ & & \\
\hline $\begin{array}{l}\text { UK-based post- } \\
\text { secondary }{ }^{*} \text { English } \\
\text { problems }\end{array}$ & & $\begin{array}{c}2.466 \\
(1.798)\end{array}$ & & & & $\begin{array}{c}2.491 \\
(2.124)\end{array}$ & & \\
\hline Years of residence & $\begin{array}{l}0.989 * \\
(0.006)\end{array}$ & $\begin{array}{c}0.990 \\
(0.006)\end{array}$ & $\begin{array}{l}0.990 * \\
(0.006)\end{array}$ & $\begin{array}{c}0.963 \\
(0.022)\end{array}$ & $\begin{array}{c}0.979 * * \\
(0.008)\end{array}$ & $\begin{array}{c}0.978 * * * \\
(0.008)\end{array}$ & $\begin{array}{c}0.979 * * \\
(0.008)\end{array}$ & $\begin{array}{c}0.998 \\
(0.044)\end{array}$ \\
\hline $\begin{array}{l}\text { Foreign post- } \\
\text { secondary } * \text { UK } \\
\text { citizen }\end{array}$ & & & $\begin{array}{c}1.119 \\
(0.238)\end{array}$ & & & & $\begin{array}{c}1.153 \\
(0.303)\end{array}$ & \\
\hline $\begin{array}{l}\text { UK-based post- } \\
\text { secondary * UK } \\
\text { citizen }\end{array}$ & & & $\begin{array}{c}0.903 \\
(0.269)\end{array}$ & & & & $\begin{array}{c}1.199 \\
(0.347)\end{array}$ & \\
\hline $\begin{array}{l}\text { Foreign post- } \\
\text { secondary } * \text { years } \\
\text { of residence }\end{array}$ & & & & $\begin{array}{c}0.964 \\
(0.039)\end{array}$ & & & & $\begin{array}{c}0.920 \\
(0.053)\end{array}$ \\
\hline $\begin{array}{l}\text { UK-based post- } \\
\text { secondary }{ }^{*} \text { years } \\
\text { of residence }\end{array}$ & & & & $\begin{array}{c}0.992 \\
(0.045)\end{array}$ & & & & $\begin{array}{c}0.944 \\
(0.050)\end{array}$ \\
\hline $\begin{array}{l}\text { Years of } \\
\text { residence }^{\wedge} 2\end{array}$ & & & & $\begin{array}{c}1.001 \\
(0.000)\end{array}$ & & & & $\begin{array}{c}0.999 \\
(0.001)\end{array}$ \\
\hline
\end{tabular}


Table A5. (Cont.) Binary logistic regression model with sequential interactions of post-secondary qualifications for men.

\begin{tabular}{|c|c|c|c|c|c|c|c|c|}
\hline & \multicolumn{4}{|c|}{ Employment } & \multicolumn{4}{|c|}{ Over-qualification } \\
\hline & Base & *English & $\begin{array}{c}* U K \\
\text { citizen }\end{array}$ & $\begin{array}{l}* \text { Years of } \\
\text { residence }\end{array}$ & Base & *English & $\begin{array}{c}* U K \\
\text { citizen }\end{array}$ & $\begin{array}{l}* \text { Years of } \\
\text { residence }\end{array}$ \\
\hline $\begin{array}{l}\text { Foreign post- } \\
\text { secondary }{ }^{*} \text { years } \\
\text { of residence^ } 2\end{array}$ & & & & $\begin{array}{c}1.001 \\
(0.001)\end{array}$ & & & & $\begin{array}{l}1.003^{*} \\
(0.001)\end{array}$ \\
\hline $\begin{array}{l}\text { UK-based post- } \\
\text { secondary }{ }^{*} \text { years } \\
\text { of residence^ } 2\end{array}$ & & & & $\begin{array}{c}1.000 \\
(0.001)\end{array}$ & & & & $\begin{array}{c}1.001 \\
(0.001)\end{array}$ \\
\hline Years of survey dummies & Yes & Yes & Yes & Yes & Yes & Yes & Yes & Yes \\
\hline $\begin{array}{l}\text { Government office } \\
\text { region dummies }\end{array}$ & Yes & Yes & Yes & Yes & Yes & Yes & Yes & Yes \\
\hline Constant & $\begin{array}{c}0.434 \\
(0.489)\end{array}$ & $\begin{array}{c}0.415 \\
(0.465)\end{array}$ & $\begin{array}{c}0.441 \\
(0.498)\end{array}$ & $\begin{array}{c}0.378 \\
(0.437)\end{array}$ & $\begin{array}{l}0.096 * \\
(0.118)\end{array}$ & $\begin{array}{l}0.107^{*} \\
(0.130)\end{array}$ & $\begin{array}{l}0.106^{*} \\
(0.135)\end{array}$ & $\begin{array}{c}0.044 * * \\
(0.061)\end{array}$ \\
\hline Observations & 9,516 & 9,516 & 9,516 & 9,516 & 7,703 & 7,703 & 7,703 & 7,703 \\
\hline
\end{tabular}

Table A6. Binary logistic regression model with sequential interactions of post-secondary qualifications for women.

\begin{tabular}{|c|c|c|c|c|c|c|c|c|}
\hline & \multicolumn{4}{|c|}{ Employment } & \multicolumn{4}{|c|}{ Over-qualification } \\
\hline & $\begin{array}{l}* \text { years of } \\
\text { residence }\end{array}$ & Base & $\begin{array}{l}* \text { years of } \\
\text { residence }\end{array}$ & Base & $\begin{array}{l}* \text { years of } \\
\text { residence }\end{array}$ & Base & $\begin{array}{l}* \text { years of } \\
\text { residence }\end{array}$ & Base \\
\hline Age & $\begin{array}{c}1.328^{* * *} \\
(0.043)\end{array}$ & $\begin{array}{c}1.339 * * * \\
(0.043)\end{array}$ & $\begin{array}{c}1.328^{* * *} \\
(0.043)\end{array}$ & $\begin{array}{c}1.331^{* * *} \\
(0.044)\end{array}$ & $\begin{array}{l}0.909 * \\
(0.048)\end{array}$ & $\begin{array}{l}0.913^{*} \\
(0.049)\end{array}$ & $\begin{array}{l}0.909 * \\
(0.048)\end{array}$ & $\begin{array}{c}0.947 \\
(0.054)\end{array}$ \\
\hline Age2 & $\begin{array}{c}0.997 * * * \\
(0.000)\end{array}$ & $\begin{array}{c}0.997^{* * *} \\
(0.000)\end{array}$ & $\begin{array}{c}0.997 * * * \\
(0.000)\end{array}$ & $\begin{array}{c}0.997 * * * \\
(0.000)\end{array}$ & $\begin{array}{c}1.001 \\
(0.001)\end{array}$ & $\begin{array}{c}1.001 \\
(0.001)\end{array}$ & $\begin{array}{c}1.001 \\
(0.001)\end{array}$ & $\begin{array}{c}1.000 \\
(0.001)\end{array}$ \\
\hline dummy: urban & $\begin{array}{c}0.834 \\
(0.161)\end{array}$ & $\begin{array}{c}0.824 \\
(0.160)\end{array}$ & $\begin{array}{c}0.832 \\
(0.161)\end{array}$ & $\begin{array}{c}0.835 \\
(0.162)\end{array}$ & $\begin{array}{c}0.728 \\
(0.167)\end{array}$ & $\begin{array}{c}0.722 \\
(0.166)\end{array}$ & $\begin{array}{c}0.724 \\
(0.166)\end{array}$ & $\begin{array}{c}0.722 \\
(0.166)\end{array}$ \\
\hline dummy: cohabit & $\begin{array}{c}0.822 * * \\
(0.080)\end{array}$ & $\begin{array}{c}0.818 * * \\
(0.080)\end{array}$ & $\begin{array}{l}0.824 * * \\
(0.080)\end{array}$ & $\begin{array}{c}0.822 * * \\
(0.081)\end{array}$ & $\begin{array}{c}0.998 \\
(0.160)\end{array}$ & $\begin{array}{c}0.998 \\
(0.160)\end{array}$ & $\begin{array}{c}0.999 \\
(0.161)\end{array}$ & $\begin{array}{c}0.991 \\
(0.160)\end{array}$ \\
\hline $\begin{array}{l}\text { dummy: dependent } \\
\text { child }\end{array}$ & $\begin{array}{c}0.254^{* * *} \\
(0.027)\end{array}$ & $\begin{array}{c}0.252^{* * *} \\
(0.027)\end{array}$ & $\begin{array}{c}0.253 * * * \\
(0.027)\end{array}$ & $\begin{array}{c}0.254^{* * *} \\
(0.028)\end{array}$ & $\begin{array}{c}0.919 \\
(0.138)\end{array}$ & $\begin{array}{c}0.917 \\
(0.138)\end{array}$ & $\begin{array}{c}0.917 \\
(0.138)\end{array}$ & $\begin{array}{c}0.925 \\
(0.140)\end{array}$ \\
\hline $\begin{array}{l}\text { dummy: poor } \\
\text { health }\end{array}$ & $\begin{array}{c}0.354 * * * \\
(0.035)\end{array}$ & $\begin{array}{c}0.351 * * * \\
(0.035)\end{array}$ & $\begin{array}{c}0.355^{* * *} \\
(0.036)\end{array}$ & $\begin{array}{c}0.355^{* * *} \\
(0.035)\end{array}$ & $\begin{array}{c}1.671 * * * \\
(0.316)\end{array}$ & $\begin{array}{c}1.658^{* * *} \\
(0.312)\end{array}$ & $\begin{array}{c}1.686 * * * \\
(0.321)\end{array}$ & $\begin{array}{c}1.705^{* * *} \\
(0.326)\end{array}$ \\
\hline dummy: UK citizen & $\begin{array}{c}0.880 \\
(0.069)\end{array}$ & $\begin{array}{l}0.879 * \\
(0.069)\end{array}$ & $\begin{array}{l}0.773 * * \\
(0.079)\end{array}$ & $\begin{array}{c}0.884 \\
(0.070)\end{array}$ & $\begin{array}{c}0.933 \\
(0.103)\end{array}$ & $\begin{array}{c}0.937 \\
(0.104)\end{array}$ & $\begin{array}{l}0.572 * * \\
(0.137)\end{array}$ & $\begin{array}{c}0.967 \\
(0.107)\end{array}$ \\
\hline $\begin{array}{l}\text { Qualifications (ref. } \\
\text { at most secondary) } \\
\text { foreign post- } \\
\text { secondary qual. }\end{array}$ & $\begin{array}{c}1.677^{* * * *} \\
(0.191)\end{array}$ & $\begin{array}{c}1.489 * * * \\
(0.185)\end{array}$ & $\begin{array}{l}1.360 * * \\
(0.198)\end{array}$ & $\begin{array}{c}0.980 \\
(0.248)\end{array}$ & $\begin{array}{c}31.269 * * * \\
(7.640)\end{array}$ & $\begin{array}{c}29.104 * * * \\
(7.697)\end{array}$ & $\begin{array}{c}20.987 * * * \\
(6.151)\end{array}$ & $\begin{array}{c}30.324 * * * \\
(14.624)\end{array}$ \\
\hline $\begin{array}{l}\text { UK-based post- } \\
\text { secondary qual. }\end{array}$ & $\begin{array}{c}3.069 * * * \\
(0.398)\end{array}$ & $\begin{array}{c}2.967 * * * \\
(0.393)\end{array}$ & $\begin{array}{c}2.517 * * * \\
(0.522)\end{array}$ & $\begin{array}{c}4.115^{* * *} \\
(1.690)\end{array}$ & $\begin{array}{c}18.127^{* * *} \\
(4.300)\end{array}$ & $\begin{array}{c}17.357 * * * \\
(4.312)\end{array}$ & $\begin{array}{c}11.650 * * * \\
(3.949)\end{array}$ & $\begin{array}{c}13.042^{* * *} \\
(7.147)\end{array}$ \\
\hline English problems & $\begin{array}{c}0.308^{* * *} \\
(0.035)\end{array}$ & $\begin{array}{c}0.264 * * * \\
(0.035)\end{array}$ & $\begin{array}{c}0.307^{* * *} \\
(0.035)\end{array}$ & $\begin{array}{c}0.309 * * * \\
(0.035)\end{array}$ & $\begin{array}{c}2.081^{* * *} \\
(0.496)\end{array}$ & $\begin{array}{c}1.721 \\
(0.736)\end{array}$ & $\begin{array}{c}2.072 * * * \\
(0.491)\end{array}$ & $\begin{array}{c}1.913 * * * \\
(0.452)\end{array}$ \\
\hline
\end{tabular}


Table A6. (Cont.) Binary logistic regression model with sequential interactions of post-secondary qualifications for women.

\begin{tabular}{|c|c|c|c|c|c|c|c|c|}
\hline & \multicolumn{4}{|c|}{ Employment } & \multicolumn{4}{|c|}{ Over-qualification } \\
\hline & $\begin{array}{l}* \text { years of } \\
\text { residence }\end{array}$ & Base & $\begin{array}{l}* \text { years of } \\
\text { residence }\end{array}$ & Base & $\begin{array}{l}* \text { years of } \\
\text { residence }\end{array}$ & Base & $\begin{array}{l}* \text { years of } \\
\text { residence }\end{array}$ & Base \\
\hline $\begin{array}{l}\text { Foreign post- } \\
\text { secondary }{ }^{*} \text { English } \\
\text { problems }\end{array}$ & & $\begin{array}{l}1.652 * * \\
(0.421)\end{array}$ & & & & $\begin{array}{c}1.456 \\
(0.790)\end{array}$ & & \\
\hline $\begin{array}{l}\text { UK-based post- } \\
\text { secondary * English } \\
\text { problems }\end{array}$ & & $\begin{array}{c}0.993 \\
(0.793)\end{array}$ & & & & $\begin{array}{c}0.896 \\
(0.662)\end{array}$ & & \\
\hline Years of residence & $\begin{array}{c}0.995 \\
(0.005)\end{array}$ & $\begin{array}{c}0.994 \\
(0.005)\end{array}$ & $\begin{array}{c}0.996 \\
(0.005)\end{array}$ & $\begin{array}{l}0.969 * \\
(0.017)\end{array}$ & $\begin{array}{c}0.994 \\
(0.008)\end{array}$ & $\begin{array}{c}0.994 \\
(0.008)\end{array}$ & $\begin{array}{c}0.995 \\
(0.008)\end{array}$ & $\begin{array}{c}0.973 \\
(0.049) \\
\end{array}$ \\
\hline $\begin{array}{l}\text { Foreign post- } \\
\text { secondary * UK citizen }\end{array}$ & & & $\begin{array}{l}1.322^{*} \\
(0.199) \\
\end{array}$ & & & $\begin{array}{l}1.741^{* *} \\
(0.462)\end{array}$ & & \\
\hline $\begin{array}{l}\text { UK-based post- } \\
\text { secondary * UK citizen }\end{array}$ & & & $\begin{array}{c}1.267 \\
(0.269) \\
\end{array}$ & & & $\begin{array}{l}1.812 * * \\
(0.537)\end{array}$ & & \\
\hline $\begin{array}{l}\text { Foreign post- } \\
\text { secondary }{ }^{*} \text { years } \\
\text { of residence }\end{array}$ & & & & $\begin{array}{c}1.093 * * * \\
(0.035)\end{array}$ & & & & $\begin{array}{c}0.957 \\
(0.058)\end{array}$ \\
\hline $\begin{array}{l}\text { UK-based post- } \\
\text { secondary }{ }^{*} \text { years } \\
\text { of residence }\end{array}$ & & & & $\begin{array}{c}0.978 \\
(0.035)\end{array}$ & & & $\begin{array}{c}1.004 \\
(0.057)\end{array}$ & \\
\hline Years of residence ${ }^{\wedge} 2$ & & & & $\begin{array}{l}1.001^{*} \\
(0.000)\end{array}$ & & & & $\begin{array}{c}1.000 \\
(0.001) \\
\end{array}$ \\
\hline $\begin{array}{l}\text { Foreign post- } \\
\text { secondary }{ }^{*} \text { years } \\
\text { of residence^ } 2\end{array}$ & & & & $\begin{array}{c}0.998 * * * \\
(0.001)\end{array}$ & & & & $\begin{array}{c}1.002 \\
(0.002)\end{array}$ \\
\hline $\begin{array}{l}\text { UK-based post- } \\
\text { secondary }{ }^{*} \text { years } \\
\text { of residence } 2\end{array}$ & & & & $\begin{array}{c}1.000 \\
(0.001)\end{array}$ & & & & $\begin{array}{l}1.001 \\
(0.001)\end{array}$ \\
\hline Years of survey dummies & Yes & Yes & Yes & Yes & Yes & Yes & Yes & Yes \\
\hline $\begin{array}{l}\text { Government office } \\
\text { region dummies }\end{array}$ & Yes & Yes & Yes & Yes & Yes & Yes & Yes & Yes \\
\hline Constant & $\begin{array}{c}0.086 * * * \\
(0.063)\end{array}$ & $\begin{array}{c}0.078 * * * \\
(0.058)\end{array}$ & $\begin{array}{c}0.097 * * * \\
(0.071)\end{array}$ & $\begin{array}{c}0.103^{* * *} \\
(0.076)\end{array}$ & $\begin{array}{c}0.256 \\
(0.359) \\
\end{array}$ & $\begin{array}{c}0.245 \\
(0.348) \\
\end{array}$ & $\begin{array}{c}0.366 \\
(0.510) \\
\end{array}$ & $\begin{array}{c}0.148 \\
(0.218) \\
\end{array}$ \\
\hline Observations & 12,790 & 12,790 & 12,790 & 12,790 & 7,401 & 7,401 & 7,401 & 7,401 \\
\hline
\end{tabular}

Notes: ${ }^{* * *} p<0.01,{ }^{* *} p<0.05, * p<0.1$; estimated gap by ethnicity and migrant status, by qualification (Post-secondary and tertiary compared to at most upper secondary, foreign and UK) overall, then separate for those with better language skills, and citizenship, and for those who were recent and long in the country for 16-64, not in education/training or retired; weighted and clustered by pid; controlling for age, education, urbanity, cohabiting, dependent child, poor health, f.e. for survey year and region.

Table A7. Binary logistic regression model on matched job and over-qualification, interacting origin with sector of work.

\begin{tabular}{lcccc}
\hline & $\begin{array}{c}\text { Matched job } \\
\text { men }\end{array}$ & $\begin{array}{c}\text { Over-qualified } \\
\text { men }\end{array}$ & $\begin{array}{c}\text { Matched job } \\
\text { women }\end{array}$ & $\begin{array}{c}\text { Over-qualified } \\
\text { women }\end{array}$ \\
\hline Age & $1.097^{* * *}$ & $0.895^{* * *}$ & $1.125^{* * *}$ & $0.888^{* * *}$ \\
& $(0.024)$ & $(0.020)$ & $(0.023)$ & $(0.018)$ \\
\hline Age2 & $0.999 * * *$ & $1.001^{* * *}$ & $0.999 * * *$ & $1.001^{* * *}$ \\
& $(0.000)$ & $(0.000)$ & $(0.000)$ & $(0.000)$ \\
\hline
\end{tabular}


Table A7. (Cont.) Binary logistic regression model on matched job and over-qualification, interacting origin with sector of work.

\begin{tabular}{|c|c|c|c|c|}
\hline & $\begin{array}{l}\text { Matched job } \\
\text { men }\end{array}$ & $\begin{array}{l}\text { Over-qualified } \\
\text { men }\end{array}$ & $\begin{array}{l}\text { Matched job } \\
\text { women }\end{array}$ & $\begin{array}{l}\text { Over-qualified } \\
\text { women }\end{array}$ \\
\hline High qualifications & $\begin{array}{l}0.843^{* *} \\
(0.062)\end{array}$ & $\begin{array}{c}2.063 * * * \\
(0.160)\end{array}$ & $\begin{array}{l}1.150 * * \\
(0.071)\end{array}$ & $\begin{array}{c}1.192 * * * \\
(0.076)\end{array}$ \\
\hline dummy: urban & $\begin{array}{c}0.978 \\
(0.077)\end{array}$ & $\begin{array}{c}1.013 \\
(0.082)\end{array}$ & $\begin{array}{c}1.067 \\
(0.071)\end{array}$ & $\begin{array}{c}1.003 \\
(0.069)\end{array}$ \\
\hline dummy: cohabit & $\begin{array}{c}1.324^{* * *} \\
(0.108)\end{array}$ & $\begin{array}{c}0.736 * * * \\
(0.062)\end{array}$ & $\begin{array}{c}1.170 * * * \\
(0.070)\end{array}$ & $\begin{array}{c}0.846 * * * \\
(0.052)\end{array}$ \\
\hline dummy: dependent child & $\begin{array}{c}0.976 \\
(0.071)\end{array}$ & $\begin{array}{c}1.041 \\
(0.079)\end{array}$ & $\begin{array}{c}0.927 \\
(0.056)\end{array}$ & $\begin{array}{c}1.097 \\
(0.068)\end{array}$ \\
\hline dummy: poor health & $\begin{array}{c}0.952 \\
(0.083)\end{array}$ & $\begin{array}{c}1.073 \\
(0.095)\end{array}$ & $\begin{array}{c}0.719 * * * \\
(0.052)\end{array}$ & $\begin{array}{c}1.474^{* * *} \\
(0.109)\end{array}$ \\
\hline dummy: UK citizen & $\begin{array}{c}0.899 \\
(0.189)\end{array}$ & $\begin{array}{c}1.072 \\
(0.223)\end{array}$ & $\begin{array}{c}1.075 \\
(0.167)\end{array}$ & $\begin{array}{c}0.937 \\
(0.146)\end{array}$ \\
\hline $\begin{array}{l}\text { Origin (ref. white British UK-borr } \\
\text { Western migrant }\end{array}$ & $\begin{array}{c}0.838 \\
(0.185)\end{array}$ & $\begin{array}{c}1.367 \\
(0.301)\end{array}$ & $\begin{array}{c}1.160 \\
(0.222)\end{array}$ & $\begin{array}{c}0.857 \\
(0.163)\end{array}$ \\
\hline New EU migrant & $\begin{array}{c}0.185^{* * *} \\
(0.065)\end{array}$ & $\begin{array}{c}6.832 * * * \\
(2.332)\end{array}$ & $\begin{array}{c}0.295^{* * *} \\
(0.093)\end{array}$ & $\begin{array}{c}3.435^{* * *} \\
(1.069)\end{array}$ \\
\hline Other white migrant & $\begin{array}{c}1.474 \\
(0.874)\end{array}$ & $\begin{array}{c}0.879 \\
(0.543)\end{array}$ & $\begin{array}{c}0.611 \\
(0.222)\end{array}$ & $\begin{array}{l}1.812^{*} \\
(0.641)\end{array}$ \\
\hline Other white UK-born & $\begin{array}{c}0.725 \\
(0.214)\end{array}$ & $\begin{array}{c}1.276 \\
(0.386)\end{array}$ & $\begin{array}{c}1.119 \\
(0.311)\end{array}$ & $\begin{array}{c}0.587^{* *} \\
(0.157)\end{array}$ \\
\hline Indian migrant & $\begin{array}{c}0.448^{* * *} \\
(0.093)\end{array}$ & $\begin{array}{c}2.695^{* * *} \\
(0.567)\end{array}$ & $\begin{array}{c}0.351^{* * *} \\
(0.096)\end{array}$ & $\begin{array}{c}3.079 * * * \\
(0.847)\end{array}$ \\
\hline Indian UK-born & $\begin{array}{c}0.622 * * \\
(0.148)\end{array}$ & $\begin{array}{c}1.775^{* *} \\
(0.430)\end{array}$ & $\begin{array}{c}0.941 \\
(0.229)\end{array}$ & $\begin{array}{c}1.073 \\
(0.265)\end{array}$ \\
\hline Pakistani/Bangladeshi migrant & $\begin{array}{c}0.227^{* * * *} \\
(0.062)\end{array}$ & $\begin{array}{c}5.283^{* * *} \\
(1.440)\end{array}$ & $\begin{array}{c}0.357 * * \\
(0.154)\end{array}$ & $\begin{array}{c}2.821^{* *} \\
(1.209)\end{array}$ \\
\hline Pakistani/Bangladeshi UK-born & $\begin{array}{c}0.520 * * \\
(0.160)\end{array}$ & $\begin{array}{c}1.238 \\
(0.443)\end{array}$ & $\begin{array}{c}0.551 * * \\
(0.153)\end{array}$ & $\begin{array}{c}1.795^{* *} \\
(0.495)\end{array}$ \\
\hline Other Asian migrant & $\begin{array}{c}0.296 * * * \\
(0.090)\end{array}$ & $\begin{array}{c}4.039 * * * \\
(1.251)\end{array}$ & $\begin{array}{c}0.557 * * \\
(0.159)\end{array}$ & $\begin{array}{c}1.990 * * \\
(0.568)\end{array}$ \\
\hline Other Asian UK-born & $\begin{array}{c}0.593 \\
(0.276)\end{array}$ & $\begin{array}{c}0.920 \\
(0.409)\end{array}$ & $\begin{array}{c}3.392 * * \\
(1.908)\end{array}$ & $\begin{array}{c}0.297 * * \\
(0.163)\end{array}$ \\
\hline Black Caribbean migrant & $\begin{array}{c}0.825 \\
(0.373)\end{array}$ & $\begin{array}{c}1.525 \\
(0.740)\end{array}$ & $\begin{array}{c}0.851 \\
(0.378)\end{array}$ & $\begin{array}{c}1.324 \\
(0.584)\end{array}$ \\
\hline Black Caribbean UK-born & $\begin{array}{c}0.656 \\
(0.258)\end{array}$ & $\begin{array}{c}1.244 \\
(0.451)\end{array}$ & $\begin{array}{c}0.825 \\
(0.227)\end{array}$ & $\begin{array}{c}1.345 \\
(0.359)\end{array}$ \\
\hline Black African migrant & $\begin{array}{c}0.166^{* * *} \\
(0.044)\end{array}$ & $\begin{array}{c}8.063 * * * \\
(2.152)\end{array}$ & $\begin{array}{c}0.523 * * \\
(0.141)\end{array}$ & $\begin{array}{c}1.907 * * \\
(0.497)\end{array}$ \\
\hline Black African UK-born & $\begin{array}{c}0.579 \\
(0.364)\end{array}$ & $\begin{array}{c}2.131 \\
(1.226)\end{array}$ & $\begin{array}{c}0.947 \\
(0.439)\end{array}$ & $\begin{array}{c}0.786 \\
(0.391)\end{array}$ \\
\hline Other migrant & $\begin{array}{c}0.353^{* * *} \\
(0.112)\end{array}$ & $\begin{array}{c}3.376 * * * \\
(1.080)\end{array}$ & $\begin{array}{c}0.422 * * \\
(0.151)\end{array}$ & $\begin{array}{c}2.422 * * \\
(0.843)\end{array}$ \\
\hline
\end{tabular}


Table A7. (Cont.) Binary logistic regression model on matched job and over-qualification, interacting origin with sector of work.

\begin{tabular}{|c|c|c|c|c|}
\hline & $\begin{array}{l}\text { Matched job } \\
\text { men }\end{array}$ & $\begin{array}{l}\text { Over-qualified } \\
\text { men }\end{array}$ & $\begin{array}{l}\text { Matched job } \\
\text { women }\end{array}$ & $\begin{array}{c}\text { Over-qualified } \\
\text { women }\end{array}$ \\
\hline Other UK-born & $\begin{array}{c}1.241 \\
(0.370)\end{array}$ & $\begin{array}{c}0.914 \\
(0.273)\end{array}$ & $\begin{array}{c}1.127 \\
(0.342)\end{array}$ & $\begin{array}{c}0.910 \\
(0.261)\end{array}$ \\
\hline dummy: public sector & $\begin{array}{c}2.132 * * * \\
(0.170)\end{array}$ & $\begin{array}{c}0.447^{* * *} \\
(0.038)\end{array}$ & $\begin{array}{c}2.542 * * * \\
(0.155)\end{array}$ & $\begin{array}{c}0.332 * * * \\
(0.021)\end{array}$ \\
\hline $\begin{array}{l}\text { Origin * public } \\
\text { Western migrant }\end{array}$ & $\begin{array}{c}1.317 \\
(0.646)\end{array}$ & $\begin{array}{c}0.744 \\
(0.378)\end{array}$ & $\begin{array}{c}1.147 \\
(0.342)\end{array}$ & $\begin{array}{c}1.076 \\
(0.330)\end{array}$ \\
\hline New EU migrant & $\begin{array}{l}9.432 * * \\
(9.310)\end{array}$ & $\begin{array}{c}0.115^{* *} \\
(0.107)\end{array}$ & $\begin{array}{c}1.988 \\
(0.940)\end{array}$ & $\begin{array}{c}0.619 \\
(0.290)\end{array}$ \\
\hline Other white migrant & $\begin{array}{c}1.710 \\
(2.260)\end{array}$ & $\begin{array}{c}0.652 \\
(0.846)\end{array}$ & $\begin{array}{c}0.770 \\
(0.514)\end{array}$ & $\begin{array}{c}1.085 \\
(0.749)\end{array}$ \\
\hline Other white UK-born & $\begin{array}{c}1.030 \\
(0.472)\end{array}$ & $\begin{array}{c}1.002 \\
(0.491)\end{array}$ & $\begin{array}{c}0.916 \\
(0.371)\end{array}$ & $\begin{array}{c}1.149 \\
(0.493)\end{array}$ \\
\hline Indian migrant & $\begin{array}{c}2.925 * * \\
(1.266)\end{array}$ & $\begin{array}{c}0.382 * * \\
(0.166)\end{array}$ & $\begin{array}{l}2.560 * * \\
(0.976)\end{array}$ & $\begin{array}{l}0.511^{*} \\
(0.191)\end{array}$ \\
\hline Indian UK-born & $\begin{array}{c}1.696 \\
(0.769)\end{array}$ & $\begin{array}{c}0.631 \\
(0.291)\end{array}$ & $\begin{array}{c}0.698 \\
(0.254)\end{array}$ & $\begin{array}{c}1.700 \\
(0.627)\end{array}$ \\
\hline Pakistani/Bangladeshi migrant & $\begin{array}{c}4.644^{* * *} \\
(1.993)\end{array}$ & $\begin{array}{c}0.214^{* * *} \\
(0.092)\end{array}$ & $\begin{array}{l}2.787^{*} \\
(1.671)\end{array}$ & $\begin{array}{c}0.441 \\
(0.266)\end{array}$ \\
\hline Pakistani/Bangladeshi UK-born & $\begin{array}{l}3.171^{* *} \\
(1.804)\end{array}$ & $\begin{array}{c}0.555 \\
(0.343)\end{array}$ & $\begin{array}{l}2.091^{*} \\
(0.797)\end{array}$ & $\begin{array}{c}0.587 \\
(0.229)\end{array}$ \\
\hline Other Asian migrant & $\begin{array}{c}5.115^{* * *} \\
(3.028)\end{array}$ & $\begin{array}{c}0.193^{* * *} \\
(0.115)\end{array}$ & $\begin{array}{l}2.501 * * \\
(1.097)\end{array}$ & $\begin{array}{l}0.459 * \\
(0.204)\end{array}$ \\
\hline Other Asian UK-born & $\begin{array}{l}3.863^{*} \\
(3.160)\end{array}$ & $\begin{array}{c}0.547 \\
(0.441)\end{array}$ & $\begin{array}{c}0.293 \\
(0.292)\end{array}$ & $\begin{array}{l}4.738^{*} \\
(4.332)\end{array}$ \\
\hline Black Caribbean migrant & $\begin{array}{c}2.945 \\
(3.328)\end{array}$ & $\begin{array}{c}0.348 \\
(0.407)\end{array}$ & $\begin{array}{c}1.023 \\
(0.543)\end{array}$ & $\begin{array}{c}1.168 \\
(0.616)\end{array}$ \\
\hline Black Caribbean UK-born & $\begin{array}{c}1.338 \\
(0.827)\end{array}$ & $\begin{array}{c}1.071 \\
(0.657)\end{array}$ & $\begin{array}{c}0.721 \\
(0.273)\end{array}$ & $\begin{array}{c}1.615 \\
(0.603)\end{array}$ \\
\hline Black African migrant & $\begin{array}{c}3.310 * * * \\
(1.508)\end{array}$ & $\begin{array}{c}0.299 * * * \\
(0.139)\end{array}$ & $\begin{array}{c}1.193 \\
(0.502)\end{array}$ & $\begin{array}{c}1.047 \\
(0.448)\end{array}$ \\
\hline Black African UK-born & $\begin{array}{l}0.190 * \\
(0.170)\end{array}$ & $\begin{array}{c}1.930 \\
(1.720)\end{array}$ & $\begin{array}{c}1.179 \\
(0.816)\end{array}$ & $\begin{array}{c}1.399 \\
(0.869)\end{array}$ \\
\hline Other migrant & $\begin{array}{c}5.183^{* * *} \\
(2.915)\end{array}$ & $\begin{array}{c}0.207^{* * *} \\
(0.118)\end{array}$ & $\begin{array}{c}1.927 \\
(0.959)\end{array}$ & $\begin{array}{c}0.659 \\
(0.328)\end{array}$ \\
\hline Other UK-born & $\begin{array}{c}0.493 \\
(0.264)\end{array}$ & $\begin{array}{c}2.112 \\
(1.150)\end{array}$ & $\begin{array}{c}0.915 \\
(0.389)\end{array}$ & $\begin{array}{c}0.808 \\
(0.320)\end{array}$ \\
\hline Constant & $\begin{array}{c}0.114^{* * *} \\
(0.057)\end{array}$ & $\begin{array}{c}9.017^{* * *} \\
(4.550)\end{array}$ & $\begin{array}{c}0.053^{* * *} \\
(0.022)\end{array}$ & $\begin{array}{c}16.119 * * * \\
(6.939)\end{array}$ \\
\hline Observations & 20,269 & 20,269 & 27,939 & 27,939 \\
\hline
\end{tabular}

Notes: $* * * p<0.01, * * p<0.05, * p<0.1$; estimated odds ratio of having qualifications matching the job or having higher than average qualifications, interacting origin with working in the public sector for 16-64, not in education/training or retired; weighted logistic regression and clustered by pid; controlling for age, education, urbanity, cohabiting, dependent child, poor health, f.e. for survey year and region. 
Table A8. Robustness tests for men: binary logistic regression of being employed rather than unemployed, and under- and over-qualification using mode.

\begin{tabular}{|c|c|c|c|}
\hline Employed (strict) $(N=69,560)$ & Low & Middle & High \\
\hline Western migrant & 0.017 & -0.033 & -0.005 \\
\hline New EU migrant & 0.022 & & 0.011 \\
\hline Other white migrant & 0.012 & $0.036 * * *$ & 0.024 \\
\hline Other white UK-born & $-0.050 * *$ & 0.007 & -0.026 \\
\hline Indian migrant & 0.009 & -0.023 & $0.014^{*}$ \\
\hline Indian UK-born & $-0.053^{*}$ & $0.034 * * *$ & -0.011 \\
\hline Pakistani/Bangladeshi migrant & -0.018 & -0.015 & 0.004 \\
\hline Pakistani/Bangladeshi UK-born & -0.010 & -0.002 & -0.034 \\
\hline Other Asian migrant & 0.012 & -0.029 & 0.005 \\
\hline Other Asian UK-born & $0.041 * *$ & $-0.121 * * *$ & -0.009 \\
\hline Black Caribbean migrant & $-0.074 *$ & -0.053 & -0.057 \\
\hline Black Caribbean UK-born & $-0.065 * * *$ & $-0.144^{* * *}$ & $-0.097 * *$ \\
\hline Black African migrant & $-0.046 * *$ & -0.020 & $-0.068 * * *$ \\
\hline Black African UK-born & -0.133 & 0.007 & -0.004 \\
\hline Other migrant & -0.013 & 0.001 & $-0.047^{*}$ \\
\hline Other UK-born & $-0.036^{*}$ & -0.063 & 0.001 \\
\hline \multicolumn{4}{|l|}{ Under-qualified ( $N=56,560)$} \\
\hline Western migrant & -0.041 & $-0.085^{*}$ & 0.009 \\
\hline New EU migrant & -0.078 & $-0.119 *$ & \\
\hline Other white migrant & -0.020 & $-0.143 * * *$ & \\
\hline Other white UK-born & 0.043 & -0.003 & -0.005 \\
\hline Indian migrant & $-0.117^{* * *}$ & & $-0.041 * * *$ \\
\hline Indian UK-born & -0.091 & $-0.134 * * *$ & -0.030 \\
\hline Pakistani/Bangladeshi migrant & $-0.193 * * *$ & & $-0.038 * * *$ \\
\hline Pakistani/Bangladeshi UK-born & $-0.263 * * *$ & -0.093 & 0.027 \\
\hline Other Asian migrant & $-0.182 * * *$ & & $-0.039 * * *$ \\
\hline Other Asian UK-born & 0.041 & & 0.031 \\
\hline Black Caribbean migrant & $0.138 *$ & & \\
\hline Black Caribbean UK-born & $-0.118^{* *}$ & 0.021 & $-0.046 * * *$ \\
\hline Black African migrant & $-0.193 * * *$ & $-0.169 * * *$ & $-0.044 * * *$ \\
\hline Black African UK-born & 0.055 & & 0.034 \\
\hline Other migrant & -0.098 & & $-0.042 * * *$ \\
\hline Other UK-born & -0.041 & $-0.141 * * *$ & $-0.039 * * *$ \\
\hline \multicolumn{4}{|l|}{ Over-qualified ( $N=57,357)$} \\
\hline Western migrant & $0.084 * *$ & 0.086 & 0.003 \\
\hline New EU migrant & $0.169 * * *$ & 0.194 & $0.490 * * *$ \\
\hline Other white migrant & $-0.053 * * *$ & -0.027 & 0.026 \\
\hline Other white UK-born & 0.015 & -0.011 & 0.016 \\
\hline Indian migrant & $0.105^{* * *}$ & 0.160 & $0.190 * * *$ \\
\hline Indian UK-born & -0.013 & $0.221 * *$ & -0.022 \\
\hline Pakistani/Bangladeshi migrant & $0.120 * * *$ & $0.418^{* * *}$ & $0.278 * * *$ \\
\hline Pakistani/Bangladeshi UK-born & 0.001 & $0.279 * *$ & 0.056 \\
\hline Other Asian migrant & $0.193 * * *$ & $0.355^{* * *}$ & $0.161 * *$ \\
\hline Other Asian UK-born & 0.094 & $0.170 * * *$ & $-0.109 * *$ \\
\hline Black Caribbean migrant & -0.012 & 0.181 & 0.064 \\
\hline Black Caribbean UK-born & $-0.025^{*}$ & 0.086 & -0.014 \\
\hline Black African migrant & $0.104 * * *$ & $0.428 * * *$ & $0.227 * * *$ \\
\hline Black African UK-born & 0.040 & -0.200 & $0.190 * *$ \\
\hline Other migrant & 0.064 & $0.386 * * *$ & $0.208 * * *$ \\
\hline
\end{tabular}


Table A8. (Cont.) Robustness tests for men: binary logistic regression of being employed rather than unemployed, and under- and over-qualification using mode.

\begin{tabular}{llrr}
\hline Over-qualified $(\mathbf{N}=\mathbf{5 7 , 3 5 7})$ & Low & Middle & High \\
\hline Other UK-born & -0.014 & 0.065 & 0.005 \\
\hline
\end{tabular}

Notes: ${ }^{* *} p<0.01,{ }^{* *} p<0.05,{ }^{*} p<0.1$; estimated average marginal effects compared to UK-born white British, by qualifications (low: at most upper secondary; middle: post-secondary non-tertiary; high: tertiary), of being employed rather than unemployed; having qualifications under the mode for occupation; and having qualifications over the mode for occupation, for 16-64, not in education/training or retired; weighted logistic regression and clustered by pid; controlling for age, education, urbanity, cohabiting, dependent child, poor health, f.e. for survey year and region.

Table A9. Robustness tests for women: Binary logistic regression of being employed rather than unemployed, and underand over-qualification using mode.

\begin{tabular}{|c|c|c|c|}
\hline Employed (strict) $(N=69,560)$ & Low & Middle & High \\
\hline Western migrant & 0.011 & -0.026 & $-0.022 * *$ \\
\hline New EU migrant & -0.009 & 0.001 & -0.007 \\
\hline Other white migrant & -0.015 & & $-0.105^{* * *}$ \\
\hline Other white UK-born & 0.010 & 0.002 & $0.015^{* *}$ \\
\hline Indian migrant & -0.009 & $0.020 * *$ & $-0.038^{* * *}$ \\
\hline Indian UK-born & -0.009 & 0.014 & -0.021 \\
\hline Pakistani/Bangladeshi migrant & $-0.084 * * *$ & $-0.209 * * *$ & $-0.082 * * *$ \\
\hline Pakistani/Bangladeshi UK-born & $-0.093 *$ & $-0.069 * *$ & $-0.034 * *$ \\
\hline Other Asian migrant & -0.061 & -0.002 & $-0.028^{*}$ \\
\hline Other Asian UK-born & -0.075 & & $-0.055^{*}$ \\
\hline Black Caribbean migrant & $-0.041^{*}$ & -0.019 & -0.031 \\
\hline Black Caribbean UK-born & $-0.031 *$ & -0.025 & $-0.044 * *$ \\
\hline Black African migrant & $-0.068 * * *$ & -0.010 & $-0.035^{* * *}$ \\
\hline Black African UK-born & $-0.082^{*}$ & 0.023 & -0.003 \\
\hline Other migrant & 0.001 & -0.023 & $-0.044 * *$ \\
\hline Other UK-born & $-0.045^{* *}$ & -0.008 & $-0.031 * *$ \\
\hline \multicolumn{4}{|l|}{ Under-qualified $(N=63,414)$} \\
\hline Western migrant & 0.036 & -0.025 & $-0.034 * *$ \\
\hline New EU migrant & -0.059 & $-0.054 * * *$ & $-0.067 * * *$ \\
\hline Other white migrant & -0.034 & -0.003 & \\
\hline Other white UK-born & $0.117 * *$ & 0.071 & 0.002 \\
\hline Indian migrant & $-0.087 * *$ & & $-0.039 *$ \\
\hline Indian UK-born & -0.025 & $-0.069 * * *$ & 0.012 \\
\hline Pakistani/Bangladeshi migrant & -0.034 & & \\
\hline Pakistani/Bangladeshi UK-born & -0.042 & $-0.064 * * *$ & -0.020 \\
\hline Other Asian migrant & -0.000 & & $-0.049 * * *$ \\
\hline Other Asian UK-born & $-0.261 * * *$ & & -0.039 \\
\hline Black Caribbean migrant & -0.077 & $-0.048 *$ & \\
\hline Black Caribbean UK-born & -0.066 & $-0.079 * * *$ & -0.023 \\
\hline Black African migrant & -0.027 & -0.031 & $-0.057 * * *$ \\
\hline Black African UK-born & -0.096 & & 0.018 \\
\hline Other migrant & -0.047 & $-0.057 * * *$ & $-0.067^{* * *}$ \\
\hline Other UK-born & 0.058 & 0.013 & 0.072 \\
\hline \multicolumn{4}{|l|}{ Over-qualified $(\mathrm{N}=64,403)$} \\
\hline Western migrant & $0.058^{* *}$ & $-0.153 * *$ & -0.045 \\
\hline New EU migrant & $0.110 * * *$ & $0.296 * * *$ & $0.263^{* * *}$ \\
\hline Other white migrant & 0.092 & 0.107 & $0.193^{* *}$ \\
\hline Other white UK-born & -0.022 & -0.106 & $-0.095^{* *}$ \\
\hline Indian migrant & $0.078 * *$ & 0.028 & $0.187^{* * *}$ \\
\hline
\end{tabular}


Table A9. Robustness tests for women: Binary logistic regression of being employed rather than unemployed, and underand over-qualification using mode.

\begin{tabular}{lccc}
\hline Over-qualified $(\mathbf{N}=\mathbf{6 4 , 4 0 3})$ & Low & Middle & High \\
\hline Indian UK-born & -0.019 & $0.256^{* * *}$ & 0.034 \\
Pakistani/Bangladeshi migrant & 0.021 & 0.053 & $0.283^{* * *}$ \\
Pakistani/Bangladeshi UK-born & $-0.029^{* *}$ & 0.095 & $0.195^{* * *}$ \\
Other Asian migrant & 0.058 & 0.043 & $0.110^{* *}$ \\
Other Asian UK-born & -0.018 & & 0.019 \\
Black Caribbean migrant & 0.063 & 0.008 & 0.071 \\
Black Caribbean UK-born & -0.016 & 0.087 & $0.096^{*}$ \\
Black African migrant & 0.038 & 0.027 & $0.176^{* * *}$ \\
Black African UK-born & $0.150^{*}$ & $0.274^{* *}$ & -0.007 \\
Other migrant & $0.160^{* *}$ & 0.109 & 0.040 \\
Other UK-born & 0.002 & $-0.125^{*}$ & 0.049 \\
\hline
\end{tabular}

Notes: ${ }^{* *} p<0.01,{ }^{* *} p<0.05,{ }^{*} p<0.1$; estimated average marginal effects compared to UK-born white British, by qualifications (low: at most upper secondary; middle: post-secondary non-tertiary; high: tertiary), of being employed rather than unemployed; having qualifications under the mode for occupation; and having qualifications over the mode for occupation; for 16-64, not in education/training or retired; weighted logistic regression and clustered by pid; controlling for age, education, urbanity, cohabiting, dependent child, poor health, f.e. for survey year and region. 